\title{
Antimicrobial efficacy of irradiation with visible light on oral bacteria in vitro: a systematic review
}

\begin{abstract}
Aim: Resistances to antibiotics employed for treatment of infectious diseases have increased to alarming numbers making it more and more difficult to treat diseases caused by microorganisms resistant to common antibiotics. Consequently, novel methods for successful inactivation of pathogens are required. In this instance, one alternative could be application of light for treatment of topical infections. Antimicrobial properties of UV light are well documented, but due to its DNAdamaging properties use for medical purposes is limited. In contrast, irradiation with visible light may be more promising. Method: Literature was systematically screened for research concerning inactivation of main oral bacterial species by means of visible light. Results: Inactivation of bacterial species, especially pigmented ones, in planktonic state showed promising results. There is a lack of research examining the situation when organized as biofilms. Conclusion: More research concerning situation in a biofilm state is required.
\end{abstract}

First draft submitted: 1 March 2017; Accepted for publication: 8 May 2017; Published online: 9 August 2017

Keywords: antimicrobial $\bullet$ bacteria $\bullet$ light $\bullet$ oral $\bullet$ visible

Far back in 1945, Sir Alexander Fleming already mentioned in his noble prize speech that there may be the ability of bacteria to get resistant to antibiotics [1]. Since then, antimicrobial resistances of microorganisms have become an increasing problem to public health making it more difficult to treat diseases caused by resistant pathogens in lack of proper treatment modalities. This can lead to severe infections or even death of patients [2]. In recent years, it has been reported that some bacterial strains have become resistant to all available antibiotics [3]. Thus, development of novel strategies for treatment of infections caused by antibiotic-resistant pathogens has to be a major research goal in life sciences. Also in the field of dentistry, administration of systemic and topic antibiotics should be reduced as much as possible for reducing the risk of inducing new resistances. Furthermore, there are more and more refractory infections of endodontic and periodontal origin caused by antibiotic-resistant pathogens $[4,5]$.

In this instance, the antimicrobial photodynamic therapy (aPDT) may be a promising alternative for topical killing of bacteria [6,7]. Usually, aPDT consists of application of an external substance, the so-called photosensitizer (PS), and subsequent irradiation with light of an appropriate wavelength, resulting in generation of reactive oxygen species (ROS) that kill bacteria by oxidative processes [8]. Pronounced inactivation rates of oral biofilms have already been shown for aPDT [9].

On the other hand, it is known that some bacteria are sensitive to irradiation with light only without the application of a light-sensitive molecule $[10,11]$. For instance, irradiation with UV light, whose spectrum is subdivided into three sections (UV-C: $100-280 \mathrm{~nm}$,
Andreas Pummer*,1, Helge Knüttel ${ }^{2}$, Karl-Anton Hiller ${ }^{1}$, Wolfgang Buchalla', Fabian Cieplik $^{1}$ \& Tim Maisch ${ }^{3}$ 'Department of Conservative Dentistry \& Periodontology, University Medical Center Regensburg, 93053 Regensburg, Germany

${ }^{2}$ University Library, University of Regensburg, 93053 Regensburg, Germany

${ }^{3}$ Department of Dermatology, University Medical Center Regensburg, 93053 Regensburg, Germany *Author for correspondence: Tel.: +499419446016 Fax: +499419446025 andreas.pummer@ukr.de 
UV-B: $280-315 \mathrm{~nm}$ and UV-A: $315-380 \mathrm{~nm}$ ), proved to be able to inactivate bacteria [12]. It was shown that its maximum bactericidal effect occurs within the UV-C range between 240-280 nm [13]. However, there are several disadvantages of using UV light in patients. It has been reported that absorption of UV-A light might result in damage of major biomolecules including DNA and membrane lipids in eukaryotic cells [14]. It is also known that UV light leads to different classes of mutagenic and cytotoxic DNA lesions [15]. High amounts of UV rays can also lead to skin cancer and eye conditions such as cataracts [16]. Thus, the usage of UV light for topical killing of pathogens may not be a proper alternative for treatment of oral infections.

Consequently, application of visible light could be an alternative for inactivation of bacteria. Visible light corresponds to wavelengths between 380 and $750 \mathrm{~nm}$ reflecting a color range from violet to red [17]. There are reports suggesting that light from the visible spectrum might lead to an autophotosensitization process inducing production of ROS in pathogens as a result of an accumulation of endogenous substances already present within biofilms or tissue that can act as PS [11]. For control of oral infections, irradiation with visible light may be a favorable approach due to the easy accessibility of the oral cavity compared with other parts of the body.

The aim of this systematic review was to assess the results of studies investigating the efficacy of treatment with visible light without external application of a PS in vitro on relevant bacteria occurring in the oral cavity.

\section{Methods}

As this systematic review does not study any healthrelated outcome of direct patient or clinical relevance, it was not considered eligible for registration in the International Prospective Register of Systematic Reviews PROSPERO.

The focused question of this systematic review was: 'Is irradiation with visible light capable of inactivating oral bacteria in vitro?'

\section{Identification of studies}

Studies were identified by searching electronic databases and scanning the reference lists of eligible articles and relevant reviews. Search strategies were developed by a subject specialist and medical librarian who is trained and experienced in conducting systematic literature searches (H Knüttel). Although we had no opportunity to have the search strategies peerreviewed, we strived to design, carry out and report the literature search according to current checklists and recommendations $[18,19]$.

In the research question, we identified three search concepts that were combined using the Boolean operator AND: 'photoinactivation,' 'bacteria' and 'oral.' For each of the concepts, search terms including synonyms were compiled and combined using the Boolean operator OR in order to compose a highly sensitive search strategy. We selected feasible search terms, relevant subject headings and appropriate syntax according to the databases and search interfaces. No limits such as for date and language were imposed at the time of searching.

We selected databases by thematic relevance and accessibility. On 22 December 2016, we searched MEDLINE (Ovid: Epub Ahead of Print, In-Process \& Other Non-Indexed Citations, Ovid MEDLINE[R] Daily and Ovid MEDLINE[R] 1946 to present), Embase (Ovid: Embase 1974 to 21 December 2016) and Web of Science (Science Citation Index Expanded 1965 to present; data last updated: 21 December 2016). A detailed documentation of the searches allowing for replication is attached in Appendix 1. References were exported from the databases and deduplication was carried out using the method of Bramer et al. [20].

The reference lists of eligible articles were scanned independently by two of the authors (subject specialists) for additional relevant articles (A Pummer, F Cieplik). Occasional articles encountered by serendipity in other sources were also included.

\section{Inclusion criteria}

In vitro studies examining inactivation of bacteria by means of visible light irradiation without addition of an exogenous light-sensitive substance were taken into consideration. Bacteria could be organized in planktonic state or in biofilm state. Only studies treating bacteria typically occurring in the oral cavity were chosen. Studies published in English or German were included as a consequence of lack of proper expertise in other languages considering scientific issues. Nevertheless, manual screening of different databases leads to the assumption that there were no relevant studies on this topic published in other languages.

\section{Exclusion criteria}

Systematic or nonsystematic reviews were excluded. However, eligible studies found in thematically relevant reviews were included. Studies treating other microorganisms than bacteria such as fungi or viruses or studies where exogenous light-sensitive substances were added to bacteria as well as studies in which illumination was performed by means of nonvisible light were not taken into consideration. Non-in vitro studies were not taken into consideration as we aimed to show susceptibility of bacteria to light itself like they occur in clinical practice without any outer influences. Moreover, studies examining bacteria that were not of 
oral origin or relevance were not included. Conference abstracts without full data or experimental details were excluded.

\section{Data organization}

A standard document, which included author(s) and year of publication, investigated microorganisms, organization of microorganisms (planktonic or biofilm), type of light source, irradiation parameters (output power and intensity, wavelength, applied energy) as well as a summary of the main outcomes was used in order to systematize data received from each report (Table 1).

\section{Results \& discussion}

\section{Study identification}

Searching of three electronic databases yielded a total of 4800 records (MEDLINE: 1411; Embase: 2010, Web of Science: 1379). After elimination of duplicates with the Bramer method, 2619 records remained [20]. Eight additional studies were found in the reference lists of the included studies and another four in other sources.

\section{Study selection}

In the first step, studies were filtered by title screening by two independent subject specialists (A Pummer, F Cieplik). Studies not relevant by topic were excluded in this step. Second, the abstracts of all of the remaining studies were read and a decision considering suitability was made. In a third step, the full-text articles were read. Only studies that were regarded as suitable after this step were included (Figure 1 for reasons of exclusion).

Screening by title left 262 records that were screened by abstract. 93 articles remained that were screened by reading the full text. Finally, a total of 34 articles relating to the same number of studies (22 articles from the database searches plus 12 studies identified in the reference lists and other sources) were considered as eligible for the review (Figure 1 for a PRISMA [Preferred reporting items for systematic reviews and meta-analyses] flow diagram of the process [54]). Table 1 shows a summary of the 34 studies selected. Table 2 lists a subset of 9 of these 34 studies, where an inactivation of $3 \log _{10}$ steps $(99.9 \%)$ or more could be achieved. The microorganism and wavelength tested is listed, as well as the light dose $\left(\mathrm{J} / \mathrm{cm}^{2}\right)$ required to achieve a $3 \log _{10}$-step reduction. An inactivation rate of $3 \log _{10}$ steps was chosen as it is declared as a biologically relevant antimicrobial activity according to infection control guidelines [53].

\section{Actinomyces actinomycetemcomitans}

König et al. used planktonic suspensions of Actinomyces odontolyticus among others and exposed them to red light $(60 \mathrm{~mW}$ helium-neon laser; $632.8 \mathrm{~nm}$; total energy density: $360 \mathrm{~J} / \mathrm{cm}^{2}$ ) [44]. The killing rate
(CFU [colony forming units] values of laser-exposed bacteria compared with CFU values of nonexposed bacteria) for $A$. odontolyticus was $70 \pm 4 \%$, whereas it was $42 \pm 10 \%$ for Propionibacterium acnes and $50 \pm$ $10 \%$ for Porphyromonas gingivalis. In contrast, no effect could be observed upon illumination of Streptococcus mutans. As a result, it can be concluded that there was no antibacterial effect (99.9\% reduction or more [53]) for neither of the tested microorganisms. Additional fluorescence measurement proved existence of intracellular protoporphyrin IX for $A$. odontolyticus as well as for $P$. acnes indicating that the observed phototoxicity might be due to an autophotosensitization process [44].

\section{Aggregatibacter spp.}

In a study from our group, planktonic suspensions of Aggregatibacter actinomycetemcomitans were irradiated with a light-emitting diode (LED) light-curing unit with an emission peak at $460 \mathrm{~nm}$ at a total energy dose of $150 \mathrm{~J} / \mathrm{cm}^{2}\left(1250 \mathrm{~mW} / \mathrm{cm}^{2} ; 120 \mathrm{~s}\right)$ [11]. This resulted in a reduction of more than $5 \log _{10}$ steps (antibacterial effect [53], Table 2) for $A$. actinomycetemcomitans, whereas there was no effect for blue-light irradiation of Escherichia coli, which was used as a control organism [11].

Spectroscopic investigations showed presence of intracellular porphyrins and flavins. Excitation at the emission peak of the light source used in the experiments $(460 \mathrm{~nm})$ showed that particularly flavins may have been causative for inactivation of A. actinomycetemcomitans by irradiation with blue light (Tables 1 \& 2) [11].

However, these results are in marked contrast to those of Song et al., who examined the effect of blue-light irradiation on $A$. actinomycetemcomitans in planktonic suspensions as well as in biofilm state [51]. A halogen lamp ( $\lambda=400-520 \mathrm{~nm}$; output power of $500 \mathrm{~mW} / \mathrm{cm}^{2}$ ) was used for the experiments. Samples were exposed to light for $15-120 \mathrm{~s}\left(7-60 \mathrm{~J} / \mathrm{cm}^{2}\right)$. There was no effect for blue-light illumination neither in planktonic nor in biofilm state for $A$. actinomycetemcomintans, whereas blue light was strongly bactericidal to P. gingivalis and Fusobacterium nucleatum in planktonic state $(100 \%$ killing after $15 \mathrm{~s}$ of irradiation in the case of $P$. gingivalis, $99.1 \%$ following $60 \mathrm{~s}$ for $F$. nucleatum, respectively [51]). Effect upon illumination of bacteria organized in biofilm state, however, was statistically significant only for $P$. gingivalis $\left(\sim 1 \log _{10}\right.$ reduction for $120 \mathrm{~s}$, no antibacterial effect [53]).

As these two studies showed totally different results for phototoxicity of $A$. actinomycetemcomitans toward blue light, no final conclusion on susceptibility of $A$. actinomycetemcomitans to visible light illumination can be drawn so far. The observed differences may be due to different light sources (LED 


\begin{tabular}{|c|c|c|c|c|}
\hline Study (year) & Microorganisms & $\begin{array}{l}\text { Wavelength, } \\
\text { maximum energy }\end{array}$ & Main outcomes & Ref. \\
\hline Bumah et al. $(2015)^{\dagger}$ & MRSA & $\begin{array}{l}-470 \mathrm{~nm}, \\
220 \mathrm{~J} / \mathrm{cm}^{2}\end{array}$ & $\begin{array}{l}\text { - Total suppression for } 220 \mathrm{~J} / \mathrm{cm}^{2} \text { for both } \\
\text { concentrations }\end{array}$ & [21] \\
\hline Bumah et al. $(2015)^{\dagger}$ & MRSA & $\begin{array}{l}-405 / 470 \mathrm{~nm}, \\
60 \mathrm{~J} / \mathrm{cm}^{2}\end{array}$ & $\begin{array}{l}-100 \% \text { suppression of MRSA colonies } \\
\text { achieved with } 405 \text { and } 470 \mathrm{~nm} \text { light }\end{array}$ & [22] \\
\hline Chebath-Taub et al. (2014) & Streptococcus mutans & $\begin{array}{l}-400-500 \mathrm{~nm}, \\
680 \mathrm{~J} / \mathrm{cm}^{2}\end{array}$ & $\begin{array}{l}\text { - Delayed antibacterial influence of blue } \\
\text { light; no effect upon capability of reforming } \\
\text { new biofilm }\end{array}$ & [23] \\
\hline Cieplik et al. $(2014)^{\dagger}$ & $\begin{array}{l}\text { Aggregatibacter } \\
\text { actinomycetemcomitans } \\
(A a), \text { Escherichia coli }\end{array}$ & $\begin{array}{l}-460 \mathrm{~nm}, \\
120 \mathrm{~J} / \mathrm{cm}^{2}\end{array}$ & $\begin{array}{l}\text { - Inactivation }>5 \log _{10} \text { for } A a\left(120 \mathrm{~J} / \mathrm{cm}^{2}\right) \\
\text { different flavins and prophyrins in } A a\end{array}$ & [11] \\
\hline $\begin{array}{l}\text { Cohen-Benneron et al. } \\
\text { (2016) }\end{array}$ & S. mutans & $\begin{array}{l}-460-480 \mathrm{~nm}, \\
262 \mathrm{~J} / \mathrm{cm}^{2}\end{array}$ & $\begin{array}{l}\text { - Regrown biofilms after illumination less } \\
\text { acidogenicity as well as lower aciduricity }\end{array}$ & [24] \\
\hline de Sousa et al. (2015) & $\begin{array}{l}\text { E. coli, Pseudomonas } \\
\text { aeruginosa, } \\
\text { Staphylococcus aureus }\end{array}$ & $-450 \mathrm{~nm}, 24 \mathrm{~J} / \mathrm{cm}^{2}$ & $\begin{array}{l}\text { - Inhibition of S. aureus }\left(0.5 \log _{10} \text { for } 6 \mathrm{~J} /\right. \\
\left.\mathrm{cm}^{2}\right) \text { higher compared with P. aeruginosa and } \\
\text { E. coli. }\end{array}$ & [25] \\
\hline de Sousa et al. (2015) & S. mutans & $-420 \mathrm{~nm}, 72 \mathrm{~J} / \mathrm{cm}^{2}$ & $\begin{array}{l}\text { - Reduction of insoluble EPS highly affected } \\
\text { by twice-daily blue light irradiation }\end{array}$ & [26] \\
\hline de Sousa et al. (2016) & $\begin{array}{l}\text { S. aureus, E. coli, } \\
\text { P. aeruginosa }\end{array}$ & $\begin{array}{l}-660 / 830 / 904 \mathrm{~nm}, \\
24 \mathrm{~J} / \mathrm{cm}^{2}\end{array}$ & $\begin{array}{l}-24 \mathrm{~J} / \mathrm{cm}^{2}(660-\mathrm{nm} \text { red light): inhibition rate } \\
\text { nearly } 80 \% \text { for S. aureus }\end{array}$ & [27] \\
\hline Enwemeka et al. (2008) & MRSA & $-405 \mathrm{~nm}, 60 \mathrm{~J} / \mathrm{cm}^{2}$ & $-55 \mathrm{~J} / \mathrm{cm}^{2}:$ nearly $90 \%$ eradication & [28] \\
\hline Enwemeka et al. (2009) & MRSA (two strains) & $-470 \mathrm{~nm}, 60 \mathrm{~J} / \mathrm{cm}^{2}$ & $\begin{array}{l}-55 \mathrm{~J} / \mathrm{cm}^{2} \text { killed more than } 90 \% \text { of both } \\
\text { strains }\end{array}$ & [29] \\
\hline Feuerstein et al. (2005) & $\begin{array}{l}\text { Porphyromonas } \\
\text { gingivalis, } \\
\text { Fusobacterium } \\
\text { nucleatum }\end{array}$ & $\begin{array}{l}-400-500 \mathrm{~nm}, \\
94 \mathrm{~J} / \mathrm{cm}^{2}\end{array}$ & $\begin{array}{l}\text { - Significant reduction under aerobic } \\
\text { conditions: nearly complete killing for } \\
\text { illumination for } 2.5 \text { min (P. gingivalis) }\end{array}$ & [30] \\
\hline Feuerstein et al. (2004) & $\begin{array}{l}\text { P. gingivalis, } \\
\text { F. nucleatum, S. faecalis, } \\
\text { S. mutans }\end{array}$ & $\begin{array}{l}-400-500 \mathrm{~nm} \\
206 \mathrm{~J} / \mathrm{cm}^{2}\end{array}$ & $\begin{array}{l}\text { - Higher inactivation rates for } P \text {. gingivalis } \\
\text { compared with } F \text {. nucleatum ( } 99.6 \% \text { for } 1 \\
\text { min with plasma arc) }\end{array}$ & [31] \\
\hline Fontana et al. (2015) & $\begin{array}{l}\text { Fusobacaterium/ } \\
\text { Prevotella spp. }\end{array}$ & $\begin{array}{l}-455 \mathrm{~nm}, \\
4.8 \mathrm{~J} / \mathrm{cm}^{2}\end{array}$ & $\begin{array}{l}\text { - Higher amounts of endogenous porphyrins } \\
\text { for Prevotella species compared with } \\
\text { Fusobacterium species }\end{array}$ & [32] \\
\hline Fukui et al. (2008) & P. gingivalis & $\begin{array}{l}-400-700 \mathrm{~nm}, \\
15 \mathrm{~J} / \mathrm{cm}^{2}\end{array}$ & $\begin{array}{l}\text { - Irradiation using } 400-410-\mathrm{nm} \text { light for } 38 \mathrm{~s} \\
\text { at } 400 \mathrm{~mW} / \mathrm{cm}^{2} \text { more than } 75 \% \text { killing rate }\end{array}$ & [33] \\
\hline Ghate et al. (2013) & $\begin{array}{l}\text { S. aureus, E. coli, } \\
\text { S. typhimurium, } \\
\text { L. monocytogens }\end{array}$ & $\begin{array}{l}-461 / 521 / 624 \mathrm{~nm} \\
686 \mathrm{~J} / \mathrm{cm}^{2}\end{array}$ & $\begin{array}{l}\text { - Approximately } 5 \log _{10} \text { inactivation using } \\
461 \text {-nm light at } 10 \text { and } 15^{\circ} \mathrm{C}\end{array}$ & [34] \\
\hline Gomez et al. (2016) & S. mutans & $\begin{array}{l}-405 \mathrm{~nm}, \\
9.26 \mathrm{~J} / \mathrm{cm}^{2}\end{array}$ & $\begin{array}{l}\text { - Addition of sucrose leads to more resistant } \\
\text { biofilms }\end{array}$ & [35] \\
\hline $\begin{array}{l}\text { Guffey and Wilborn } \\
\text { (2006) }\end{array}$ & $\begin{array}{l}\text { S. aureus, } P \text {. aeruginosa, } \\
\text { Propionibacterium } \\
\text { acnes }\end{array}$ & $\begin{array}{l}-405 / 470 \mathrm{~nm}, \\
15 \mathrm{~J} / \mathrm{cm}^{2}\end{array}$ & $\begin{array}{l}\text { - } 405-\mathrm{nm} \text { light killed } S \text {. aureus at all the } \\
\text { tested doses, no bactericidal effect with } \\
\text { anaerobic } P \text {. acnes }\end{array}$ & [36] \\
\hline Henry et al. (1995) & $\begin{array}{l}\text { Prevotella and } \\
\text { Porphyromonas }\end{array}$ & $\begin{array}{l}-488-514 \mathrm{~nm}, \\
200 \mathrm{~J} / \mathrm{cm}^{2}\end{array}$ & $\begin{array}{l}\text { - Black-pigmented bacteria (Prevotella and } \\
\text { Porphyromonas species) most susceptible to } \\
\text { visible-light irradiation }\end{array}$ & [37] \\
\hline
\end{tabular}




\begin{tabular}{|c|c|c|c|c|}
\hline Study (year) & Microorganisms & $\begin{array}{l}\text { Wavelength, } \\
\text { maximum energy }\end{array}$ & Main outcomes & Ref. \\
\hline Henry et al. (1996) & $\begin{array}{l}\text { Different bacterial } \\
\text { species, Candida }\end{array}$ & $\begin{array}{l}-488-514 \mathrm{~nm} \\
35-80 \mathrm{~J} / \mathrm{cm}^{2}\end{array}$ & $\begin{array}{l}\text { - Biofilm age, presence of oxygen, } \\
\text { inoculation medium crucial for level of } \\
\text { inactivation }\end{array}$ & [38] \\
\hline Hope et al. (2013) & P. gingivalis, E. faecalis & $\begin{array}{l}-405 \mathrm{~nm}, \\
98.55 \mathrm{~J} / \mathrm{cm}^{2}\end{array}$ & - Laser pointer: $94.50 \%$ killing for $98.55 \mathrm{~J} / \mathrm{cm}^{2}$ & [39] \\
\hline Hope et al. $(2016)^{\dagger}$ & $\begin{array}{l}P . \text { intermedia, } \\
P . \text { nigrescens, S. aureus, } \\
\text { E. coli, E. faecalis }\end{array}$ & $\begin{array}{l}-405 \mathrm{~nm} \\
5.7 \mathrm{~J} / \mathrm{cm}^{2}\end{array}$ & $\begin{array}{l}-P \text {. intermedia } 99.56 \% \text { killed after } 5 \mathrm{~s} \text {, } \\
99.996 \% \text { after } 60 \mathrm{~s}\end{array}$ & [40] \\
\hline Imamura et al. (2014) & $\begin{array}{l}P . \text { intermedia, } P \text {. } \\
\text { gingivalis, E. coli, } \\
\text { C. albicans }\end{array}$ & $-405 \mathrm{~nm}, 6 \mathrm{~J}$ & $\begin{array}{l}\text { - Inhibition rates for } P \text {. intermedia and } \\
P . \text { gingivalis similar (maximum: } 80 \% \text { ) }\end{array}$ & [41] \\
\hline Izzo and Walsh (2004) & P. gingivalis & $\begin{array}{l}-455 / 625 \mathrm{~nm}, \\
1.5 \mathrm{~kJ} / \mathrm{cm}^{2}\end{array}$ & $\begin{array}{l}\text { - Temperature increase may be responsible } \\
\text { for suppression of } P \text {. gingivalis }\end{array}$ & [42] \\
\hline Kim et al. (2013) & $\begin{array}{l}\text { P. gingivalis, S. aureus, } \\
\text { E. coli }\end{array}$ & $\begin{array}{l}-425 / 525 / 625 \mathrm{~nm}, \\
172.8 \mathrm{~J}\end{array}$ & $\begin{array}{l}-425 \mathrm{~nm} \text { strongest effect followed by } 525 \\
\mathrm{~nm} ; 625 \mathrm{~nm} \text { no effect }\end{array}$ & [43] \\
\hline König et al. (2000) & $\begin{array}{l}\text { Actinomyces } \\
\text { odontolyticus, P. acnes, } \\
\text { P. gingivalis, S. mutans }\end{array}$ & $\begin{array}{l}-632.8 \mathrm{~nm} \\
360 \mathrm{~J} / \mathrm{cm}^{2}\end{array}$ & - Highest killing rate for $P$. gingivalis $(50 \%)$ & [44] \\
\hline Kotoku et al. $(2009)^{\dagger}$ & P. gingivalis & $\begin{array}{l}-405 \mathrm{~nm}, \\
16.0 \mathrm{~J} / \mathrm{cm}^{2}\end{array}$ & $\begin{array}{l}\text { - } 16.0 \mathrm{~J} / \mathrm{cm}^{2}: \text { complete eradication of } P \text {. } \\
\text { gingivalis }\end{array}$ & {$[45]$} \\
\hline Lipovsky et al. (2009) & S. aureus strains & $\begin{array}{l}-400-800 \mathrm{~nm}, \\
180 \mathrm{~J} / \mathrm{cm}^{2}\end{array}$ & $\begin{array}{l}\text { - Maximum inactivation rate: } 99.8 \% \text { at } \\
180 \mathrm{~J} / \mathrm{cm}^{2}\end{array}$ & [46] \\
\hline McKenzie et al. (2013) & $\begin{array}{l}\text { S. aureus, } \\
\text { L. monocytogenes, } \\
\text { P. aeruginosa }\end{array}$ & $\begin{array}{l}-405 \mathrm{~nm} \\
504 \mathrm{~J} / \mathrm{cm}^{2}\end{array}$ & $\begin{array}{l}\text { - Most rapid and effective inactivation } \\
\text { for } E \text {. coli monolayer biofilms }\left(3.55 \log _{10}\right. \\
\text { reduction for } 20 \mathrm{~min})\end{array}$ & {$[47]$} \\
\hline Maclean et al. $(2008)^{\dagger}$ & S. aueus, E. coli & $\begin{array}{l}->400 \mathrm{~nm} \\
630 \mathrm{~J} / \mathrm{cm}^{2}\end{array}$ & $\begin{array}{l}\text { - Maximum reduction at } 405 \mathrm{~nm} \text { at a total } \\
\text { dose of } 23.5 \mathrm{~J} / \mathrm{cm}^{2}\left(2.4 \log _{10} \text { steps }\right)\end{array}$ & [48] \\
\hline Maclean et al. (2009) ${ }^{\dagger}$ & $\begin{array}{l}\text { S. aureus, S. pyogenes, } \\
\text { control organisms }\end{array}$ & $-405 \mathrm{~nm}, 54 \mathrm{~J}$ & $-5 \log _{10}$ steps for S. pyogenes for $54 \mathrm{~J} / \mathrm{cm}^{2}$ & [49] \\
\hline $\begin{array}{l}\text { Masson-Meyers et al. } \\
(2015)\end{array}$ & MRSA & $\begin{array}{l}-405 \mathrm{~nm}, \\
121 \mathrm{~J} / \mathrm{cm}^{2}\end{array}$ & $\begin{array}{l}\text { - 405-nm light antimicrobial against MRSA, } \\
\text { regardless if using LED or laser light }\end{array}$ & [50] \\
\hline Song et al. $(2013)^{\dagger}$ & $\begin{array}{l}\text { Aa, F. nucleatum, } \\
\text { P. gingivalis }\end{array}$ & $\begin{array}{l}-400-520 \mathrm{~nm}, \\
6 \mathrm{~J} / \mathrm{cm}^{2}\end{array}$ & $\begin{array}{l}\text { - Nearly } 100 \% \text { killing for } 15 \mathrm{~s} \text { in the case of } \\
\text { P. gingivalis }\end{array}$ & {$[51]$} \\
\hline Soukos et al. $(2005)^{\dagger}$ & $\begin{array}{l}\text { Prevotall/ } \\
\text { Porphyromonas spp., } \\
\text { S. constellatus }\end{array}$ & $\begin{array}{l}-380-520 \mathrm{~nm}, \\
42 \mathrm{~J} / \mathrm{cm}^{2}\end{array}$ & $\begin{array}{l}-4.2 \mathrm{~J} / \mathrm{cm}^{2} \text { : complete killing of } P \text {. intermedia } \\
\text { and } P \text {. nigrescens different endogenous } \\
\text { porphyrins for Prevotella strains }\end{array}$ & {$[52]$} \\
\hline
\end{tabular}

light source in the first study [11], halogen lamp in the second study [51]) or due to different strains (ATCC 43718 [11] and ATCC 33384 [51], respectively) used for experiments.

As the first study clearly showed presence of flavins and porphyrins, killing by means of visible light could be a proper treatment modality for controlling infections caused by $A$. actinomycetemcomitans. In order to maintain the best results possible, light units showing broad overlap with the absorption spectra of both flavins and porphyrins should be used for irradiation.

\section{Fusobacterium spp.}

Song et al. tested $F$. nucleatum in planktonic state as well as in biofilm state [51]. Each bacterial sample was exposed to light from a halogen lamp $(\lambda=400-$ $520 \mathrm{~nm}$; output power of $500 \mathrm{~mW} / \mathrm{cm}^{2}$ ) for $15-120 \mathrm{~s}$ $\left(7.5-60 \mathrm{~J} / \mathrm{cm}^{2}\right)$. 99.1\% reduction for planktonic bacteria was achieved after illumination for $60 \mathrm{~s}\left(<3 \log _{10}\right.$, 


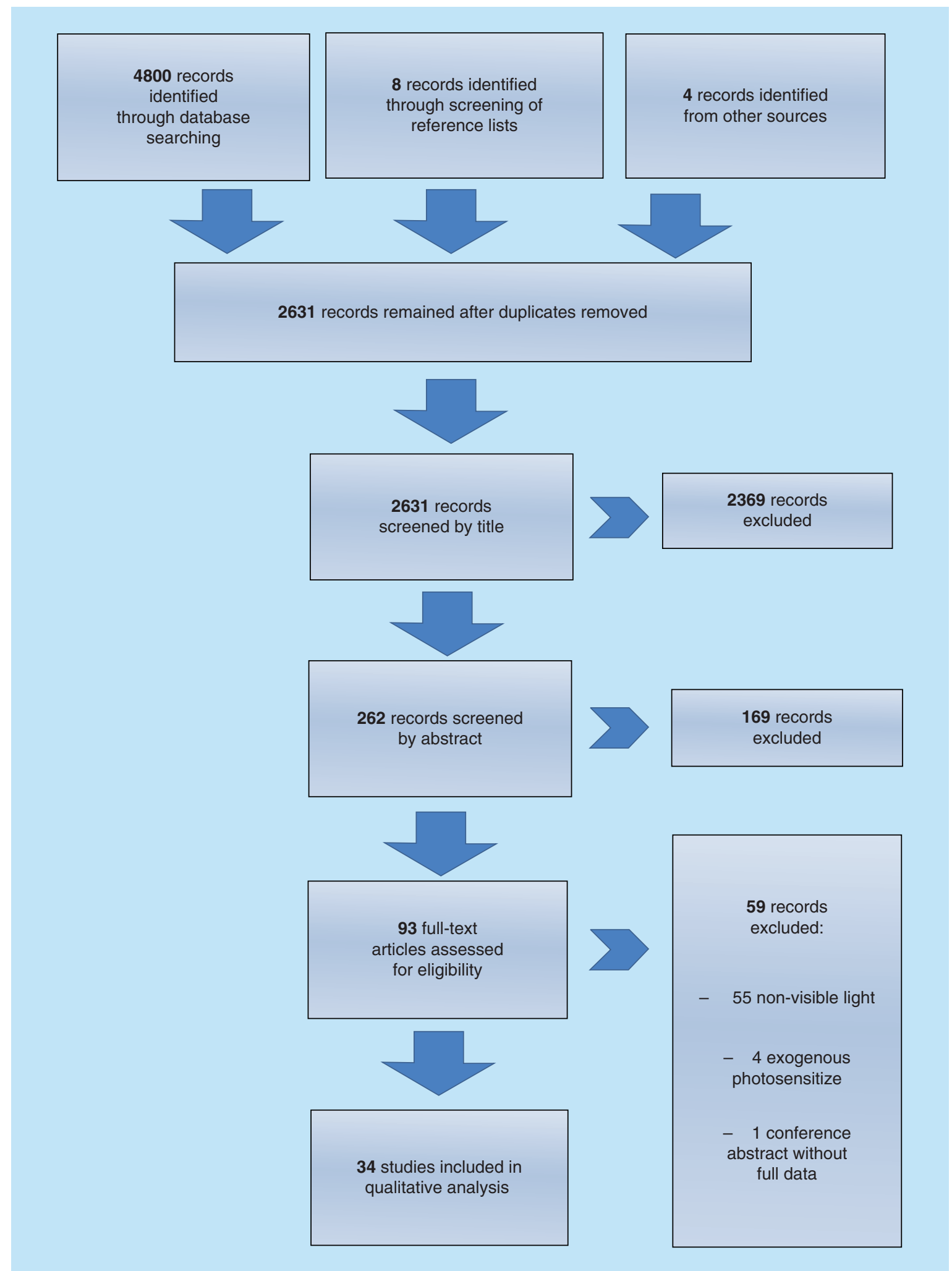

Figure 1. Flowchart of the search strategy as well as study selection and data management procedure.

no antibacterial effect [53]), whereas there was no effect on $F$. nucleatum organized as biofilm for any irradiation period tested. Inactivation rates were slightly higher for
$P$. gingivalis under the same conditions (antibacterial effect [53]), whereas $A$. actinomycetemcomitans was not susceptible to visible light irradiation in any case (Table 1). 
In another study, the effect of blue light from three different light sources was investigated for inactivation of planktonic $F$. nucleatum - two halogen lamps combined with filters (400-500 nm), a filtered xenon light source (plasma arc; 450-490 $\mathrm{nm}$ ) and an LED (450$480 \mathrm{~nm}$ ) [31]. Samples of bacteria in suspension and single bacteria on agar were exposed to light from the halogen lamps (260 and $\left.416 \mathrm{~mW} / \mathrm{cm}^{2} ; 16-75 \mathrm{~J} / \mathrm{cm}^{2}\right)$, the LED $\left(520 \mathrm{~mW} / \mathrm{cm}^{2} ; 31-94 \mathrm{~J} / \mathrm{cm}^{2}\right)$ and the plasma arc $\left(1144 \mathrm{~mW} / \mathrm{cm}^{2} ; 69-206 \mathrm{~J} / \mathrm{cm}^{2}\right)$. Corresponding irradiation periods for every sample were $1-3 \mathrm{~min}$. As a result, higher inactivation rates could be detected when irradiation on agar plates was done in comparison to irradiation of planktonic cultures: $2.5 \mathrm{~min}$ with halogen lamp 2 resulted 'in nearly zero survival' [31] when irradiated on agar (no antibacterial effect [53]), whereas the survival rate was determined to be $40 \%$ when performed in suspension. Irradiation of $P$. gingivalis yielded higher inactivation rates compared with $F$. nucleatum $(99.6 \%$ for $1 \mathrm{~min}$ with the plasma arc). Inactivation rates were below $99.9 \%$ in all cases meaning that no antibacterial effect was achieved [53].

In addition, in this study the effect of blue light was evaluated on a bacterial lawn (minimal fluence required for inhibiting bacterial lawn from growing into biofilm: minimal inhibitory dose [MID]). The MID for $P$. gingivalis and $F$. nucleatum was determined as $16-62 \mathrm{~J} / \mathrm{cm}^{2}$, whereas MID for $S$. mutans and $S$. faecalis was $159-212 \mathrm{~J} / \mathrm{cm}^{2}(\sim 3 \mathrm{~min})$, indicating that the Streptococcus strains tested were less susceptible to blue-light irradiation.

In a another study, the same group tested blue-light inactivation of bacteria under aerobic and anaerobic conditions as well as in presence of scavengers of ROS (dimethylthiourea, superoxide dismutase, ascorbic acid or a 'cocktail' of all three scavengers) on planktonic bacteria (for light sources, see [31]) [30]. There were no significant reduction rates for illumination under anaerobic conditions, whereas significant reduction could be detected in aerobic environment (nearly complete eradication for illumination for 2.5 and $3 \mathrm{~min}$ with LED for $P$. gingivalis and $F$. nucleatum; $3 \mathrm{~min}$ corresponding to $94 \mathrm{~J} / \mathrm{cm}^{2}$; no exact data presented, only figures). Effect for $F$. nucleatum was smaller compared with $P$. gingivalis for all experiments, suggesting that $P$. gingivalis might be more susceptible to killing by blue light (no antibacterial effect in any case [53]).

Addition of the scavengers only led to virtually smaller inactivation. For these experiments, only the halogen lamps and the plasma arc were used. The authors assumed that protection was incomplete due to inefficient access of the scavengers into the bacterial cells and inactivation might be due to photodynamic processes. In addition, poor inactivation under anaerobic conditions indicate that oxygen is necessary for inactivation of bacteria or that production of endogenous light-sensitive molecules may be downregulated under anaerobic conditions.

\begin{tabular}{|c|c|c|c|c|}
\hline Study (year) & Microorganism & Wavelength & $\begin{array}{l}\text { Required dose for } 3 \log _{10^{-}} \\
\text {step reduction or more }\end{array}$ & Ref. \\
\hline Bumah et al. (2015) & MRSA & $470 \mathrm{~nm}$ & $220 \mathrm{~J} / \mathrm{cm}^{2}$ & [21] \\
\hline Bumah et al. (2015) & MRSA & $470 \mathrm{~nm}$ & $55 \mathrm{~J} / \mathrm{cm}^{2}$ & {$[22]$} \\
\hline Cieplik et al. (2014) & A. actinomycetemcomitans & $460 \mathrm{~nm}$ & $150 \mathrm{~J} / \mathrm{cm}^{2}$ & {$[11]$} \\
\hline Ghate et al. (2013) & S. aureus & $461 \mathrm{~nm}$ & $597 \mathrm{~J} / \mathrm{cm}^{2}$ & [34] \\
\hline Hope et al. (2016) & P. intermedia & $405 \mathrm{~nm}$ & $20.6 \mathrm{~J} / \mathrm{cm}^{2}$ & {$[40]$} \\
\hline Kotokou et al. (2009) & $P$. gingivalis & $405 \mathrm{~nm}$ & $16 \mathrm{~J} / \mathrm{cm}^{2}$ & {$[45]$} \\
\hline Maclean et al. (2008) & S. aureus & $>400 \mathrm{~nm}$ & $420 \mathrm{~J} / \mathrm{cm}^{2}$ & {$[48]$} \\
\hline \multirow[t]{3}{*}{ Maclean et al. (2009) } & MRSA & $405 \mathrm{~nm}$ & $45 \mathrm{~J} / \mathrm{cm}^{2}$ & \multirow[t]{3}{*}{ [49] } \\
\hline & S. aureus & $405 \mathrm{~nm}$ & $36 \mathrm{~J} / \mathrm{cm}^{2}$ & \\
\hline & S. pyogenes & $405 \mathrm{~nm}$ & $54 \mathrm{~J} / \mathrm{cm}^{2}$ & \\
\hline Song et al. (2013) & P. gingivalis & $400-520 \mathrm{~nm}$ & $0.75 \mathrm{~J} / \mathrm{cm}^{2}$ & {$[51]$} \\
\hline \multirow[t]{3}{*}{ Soukos et al. (2005) } & P. intermedia & $380-520 \mathrm{~nm}$ & $4.2 \mathrm{~J} / \mathrm{cm}^{2}$ & \multirow[t]{3}{*}[52]{} \\
\hline & P. melanogenica & $380-520 \mathrm{~nm}$ & $21 \mathrm{~J} / \mathrm{cm}^{2}$ & \\
\hline & P. nigrescens & $380-520 \mathrm{~nm}$ & $4.2 \mathrm{~J} / \mathrm{cm}^{2}$ & \\
\hline
\end{tabular}

${ }^{+}$Antibacterial effect [53].

MRSA: Methicillin-resistant Staphylococcus aureus. 
Fontana et al. used different Fusobacterium spp. for their experiments ( $F$. nucleatum ss. nucleatum, $F$. nucleatum ss. polymorphum, F. nucleatum ss. vincentii, $F$. periodonticum) [32]. Irradiation of bacteria was performed using LED light at a wavelength of $455 \mathrm{~nm}$ at $80 \mathrm{~mW} / \mathrm{cm}^{2}$. Irradiation time was $60 \mathrm{~s}$ corresponding to an energy fluence of $4.8 \mathrm{~J} / \mathrm{cm}^{2}$. Killing rates were $46.9 \%$ for ss. nucleatum, $66.6 \%$ for ss. peridonticum, $67.4 \%$ for ss. vincentii and $93.6 \%$ ss. polymorphium, respectively. No antibacterial effect (3 $\log _{10}$-steps reduction or more [53]) could be shown for any of the tested species.

These studies suggest that different Fusobacterium strains might be susceptible to blue-light irradiation, but inactivation rates are lower compared with more pigmented genera (Porphyromonas, Prevotella). This might be due to lower amounts of endogenous porphyrins, as it was shown by the group of Fontana et al. [32].

\section{Porphyromonas spp.}

Kim et al. evaluated the efficacy of three different wavelengths for inactivating $P$. gingivalis (three-inone mounted LED package, peaks at 425, 525 and $625 \mathrm{~nm}$ corresponding to blue, green and red light, respectively) [43]. Irradiation was performed for $0-24 \mathrm{~h}$ with an average output power of $6 \mathrm{~mW} / \mathrm{cm}^{2}$ per hour $\left(48-144 \mathrm{~J} / \mathrm{cm}^{2}\right)$. At a wavelengths of 425 and $525 \mathrm{~nm}$, viability was decreased by $40-60 \%$ and $10-20 \%$, respectively. No bactericidal effect was observed for $625 \mathrm{~nm}$. 'For the suspensions containing $2 \times 10^{8}$ $\mathrm{CFU} / \mathrm{ml}$, the optical density $(\mathrm{OD})_{600}$ was decreased at $425 \mathrm{~nm}$ by $90-100 \%$ at all time points' [43] and $40-70 \%$ by $525-\mathrm{nm}$ light after $8 \mathrm{~h}$, whereas viability increased when irradiated with 625-nm light for $8 \mathrm{~h}$. These results suggest that $425 \mathrm{~nm}$ is most effective in inactivating and suppressing $P$. gingivalis, followed by 525-nm light. 625-nm light did not show any effect for any case tested. As there is no accurate description concerning exact percentage of reduction, the observed effect cannot be declared as an antibacterial effect [53].

Feuerstein et al. investigated the phototoxicity of light from three different light sources (halogen lamp with a mounted filter, $\lambda=400-500 \mathrm{~nm}$, $260 \mathrm{~mW} / \mathrm{cm}^{2}$; a filtered xenon light source, $\lambda=$ 450-490 nm, $1144 \mathrm{~mW} / \mathrm{cm}^{2}$; LED, $\lambda=450-480$ $\mathrm{nm}, 520 \mathrm{~mW} / \mathrm{cm}^{2}$ ) [30]. Using the LED, samples of $F$. nucleatum and $P$. gingivalis were irradiated for 1-3 min, corresponding to fluences of $31-94 \mathrm{~J} / \mathrm{cm}^{2}$, respectively. Inactivation only occurred under aerobic conditions ( $P$. gingivalis nearly $80 \%$ for $1 \mathrm{~min}$; for further details, see Table 1 and the Fusobacterium spp. chapter; no antibacterial effect [53] in any case).
In another study [31], the same group performed irradiation experiments using two halogen lamps combined with filters (Halogen 1 and Halogen 2; 260 and $\left.416 \mathrm{~mW} / \mathrm{cm}^{2} ; \lambda=400-500 \mathrm{~nm}\right)$, an LED and a filtered plasma arc (xenon light source; for details, see [30]). Irradiation periods were $1,1.5,2,2.5$ or $3 \mathrm{~min}$, resulting in fluences of $16-75 \mathrm{~J} / \mathrm{cm}^{2}$ for the halogen lamps, $31-94 \mathrm{~J} / \mathrm{cm}^{2}$ for the LED and $69-206 \mathrm{~J} / \mathrm{cm}^{2}$ for the plasma arc. As a result, inactivation was higher with the LED and plasma-arc light source compared with the halogen lamp, which probably was due to the higher output powers (1144 and $520 \mathrm{~mW} / \mathrm{cm}^{2}$ for plasma arc and LED, respectively; 260 and $416 \mathrm{~mW} / \mathrm{cm}^{2}$ for halogen lamps; $99.6 \%$ killing efficacy in suspension for $1 \mathrm{~min}$ with the plasma arc for $P$. gingivalis; no antibacterial effect according to [53]; compare Table 1).

Henry et al. performed their experiments using an argon laser $\left(\lambda=488-514 \mathrm{~nm} ; 20-200 \mathrm{~J} / \mathrm{cm}^{2}\right)$ [37,38]. They were able to inactivate different Prevotella spp. (P. intermedia ATCC 15033 and 49046; P. denticola ATCC 33184) and P. gingivalis (strains ATCC 33277 and ATCC 350406) [37]. P. intermedia ATCC 15033 was most sensitive to irradiation 'with no cells surviving fluences of $70 \mathrm{~J} / \mathrm{cm}^{2}$ or greater' [37]. Because no exact data are presented, it was not possible to decide if there was an antibacterial effect [53]. In addition, they tested if replacement of hemin in the medium against hemoglobin had any influence in susceptibility to laser irradiation. They could show that one P. gingivalis strain (ATCC 33277) became tolerant to light irradiation in this case, indicating that hemin could be an essential factor for production of endogenous light-sensitive molecules. Also, the authors concluded that environmental oxygen is required for visible light inactivation. In general, nonblack-pigmented bacteria were much less sensitive to irradiation compared with black-pigmented bacteria

In a second study, the same group tested the susceptibility of bacteria organized in a biofilm grown on agar medium using the same argon laser [38]. Fluences of $35-80 \mathrm{~J} / \mathrm{cm}^{2}$ were able to inhibit biofilm growth of $P$. endodontalis, $P$. gingivalis as well as of different Prevotella spp, while there was no effect on the genera Bacillus, Candida, Enterobacter, Proteus, Psuedomonas, Staphylococcus and Streptococcus applying a fluence of $70 \mathrm{~J} / \mathrm{cm}^{2}$ (Table 1). The level of inactivation was affected by different parameters such as the biofilm age, presence of atmospheric oxygen or medium used for bacterial inoculation. Overall, the results were in accordance with the first study, suggesting that inactivation of different Prevotella and Porphyromonas species might be possible in planktonic as well as in biofilm state using an argon laser (no antibacterial effect [53] in any case). 
Hope et al. irradiated a $P$. gingivalis suspension in 96-well plates [39]. Irradiation was performed using the LEDs from a 'toothcare device' $(\lambda=405 \mathrm{~nm}$; power output: $3.2 \mathrm{~mW})$ as well as a laser pointer $(\lambda=405 \mathrm{~nm}$; power output: $42.7 \mathrm{~mW}$ ) for 30,60 and $300 \mathrm{~s}$, corresponding to fluences of $0.34,0.68$ and $3.42 \mathrm{~J} / \mathrm{cm}^{2}$, respectively, for the toothcare device, whereas in the case of the laser $0.5,1$ and $5 \mathrm{~min}$, corresponding to 9.86, 19.71 and $98.55 \mathrm{~J} / \mathrm{cm}^{2}$, respectively, were chosen. Irradiation with the LEDs was performed using $E$. faecalis as control organism under the same conditions as described for $P$. gingivalis. Irradiation at a fluence of $0.34 \mathrm{~J} / \mathrm{cm}^{2}$ with the LEDs resulted in a killing efficacy of $63.41 \%$, whereas the killing rate at a fluence of $3.42 \mathrm{~J} / \mathrm{cm}^{2}$ was $94.11 \%$. Using the laser pointer, killing rates were $90.21 \%$ for $9.86 \mathrm{~J} / \mathrm{cm}^{2}$ and $94.50 \%$ for $98.55 \mathrm{~J} / \mathrm{cm}^{2}$. There was no effect on $E$. faecalis upon irradiation. In neither case, there was an inactivation rate of $3 \log _{10}$ steps or more [53].

Song et al. used a halogen lamp (dental-curing unit; 3M Curing Light XL3000, 3M ESPE, MN, USA; $\lambda=$ $\left.400-520 \mathrm{~nm} ; 500 \mathrm{~mW} / \mathrm{cm}^{2}\right)$ for irradiation of bacteria both in planktonic as well as in biofilm state $\left(6.5 \mathrm{~J} / \mathrm{cm}^{2}\right.$ up to $60 \mathrm{~J} / \mathrm{cm}^{2}$ ) [51]. The killing rate for $P$. gingivalis in planktonic state was below detection limit with an irradiation time of only $15 \mathrm{~s}$ (antibacterial effect [53], Table 2). When investigating visible light susceptibility of bacteria organized in a biofilm, only $P$. gingivalis could be killed using the same irradiation procedure as it was used with planktonic bacteria. A. actinomycetemcomitans and $F$. nucleatum were not susceptible to inactivation by visible light irradiation when organized as biofilms (no antibacterial effect [53] in any case).

Soukos et al. used a halogen lamp $(\lambda=380-520 \mathrm{~nm}$; $70 \mathrm{~mW} / \mathrm{cm}^{2} ; 0-42 \mathrm{~J} / \mathrm{cm}^{2}$ ) for irradiation of different black-pigmented bacteria [52]. Survival fractions for $P$. gingivalis were $77.25 \%\left(4.2 \mathrm{~J} / \mathrm{cm}^{2}\right), 12.55 \%$ $\left(21 \mathrm{~J} / \mathrm{cm}^{2}\right)$ and $1.48 \%\left(42 \mathrm{~J} / \mathrm{cm}^{2}\right)$. Killing rates for the tested Prevotella species ( $P$. intermedia, $P$. nigrescens, $P$. elanogenica) were higher compared with those of $P$. gingivalis. In contrast, $S$. constellatus, a nonpigmented species, was not killed under the same conditions, suggesting that pigmentation of bacteria is an important factor for visible light phototoxicity. No antibacterial effect [53] occurred in any case.

Fukui et al. aimed to determine the most effective wavelength for bacterial growth inhibition [33]. In course of this, planktonic $P$. gingivalis was exposed to monochromatic light using an Okazaki large spectrograph $(\lambda=400-700 \mathrm{~nm}$ in $10-20-\mathrm{nm}$ steps; $\left.50-400 \mathrm{~mW} / \mathrm{cm}^{2} ; 18 \mathrm{~J} / \mathrm{cm}^{2}\right)$. Significant inhibition of $P$. gingivalis occurred between 400 and $410 \mathrm{~nm}$, whereas no significant growth inhibition could be found when irradiation was performed at wavelengths longer than $500 \mathrm{~nm}$. For example, irradiation using $400-410-\mathrm{nm}$ light for $38 \mathrm{~s}$ at $400 \mathrm{~mW} / \mathrm{cm}^{2}$ resulted in a killing rate of more than $75 \%$ compared with nonirradiated control (no antibacterial effect [53]).

Fontana et al. exposed $P$. gingivalis to an LED emitting light at $455 \mathrm{~nm}\left(80 \mathrm{~mW} / \mathrm{cm}^{2}\right)$ [32]. Irradiation time was $60 \mathrm{~s}$ corresponding to an energy fluence of $4.8 \mathrm{~J} / \mathrm{cm}^{2}$. The killing rate for $P$. gingivalis was $20.3 \%$ (no antibacterial effect [53]).

Furthermore, Kotoku et al. also performed phototoxicity experiments on $P$. gingivalis using a violet laser diode module of oscillating wavelength at $405 \mathrm{~nm}$ (200-800 $\mathrm{mW} / \mathrm{cm}^{2} ; 2.0-16.0 \mathrm{~J} / \mathrm{cm}^{2}$ ) [45]. An energy density of $4 \mathrm{~J} / \mathrm{cm}^{2}$ led to growth inhibition of more than $97 \%$, while $16 \mathrm{~J} / \mathrm{cm}^{2}$ (20 s of irradiation) resulted in nearly complete eradication of $P$. gingivalis (antibacterial effect [53], Table 2). In general, higher output powers resulted in higher inactivation rates $(400 \mathrm{~mW}$ for $5 \mathrm{~s}$ resulted in significant higher inactivation rates than $200 \mathrm{~mW}$ for $10 \mathrm{~s} ; 2 \mathrm{~J} / \mathrm{cm}^{2}$, respectively).

Another study examined bacteria in suspension exposed to light from a helium-neon laser $(\lambda=632.8$ $\mathrm{nm}$ red light; light intensity of $100 \mathrm{~mW} / \mathrm{cm}^{2}$; fluence of $360 \mathrm{~J} / \mathrm{cm}^{2}$ ) [44]. The killing rate for $P$. gingivalis was $41 \pm 10 \%(70 \% \pm 4 \%$ for $A$. odontolyticus; $42 \pm 9 \%$ for $P$. acnes; no effect for $S$. mutans). Additional testing of susceptibility of wild-type $P$. gingivalis isolated from plaque samples showed a killing rate of $41 \pm 26 \%$ (Prevotella spp. $58 \pm 14 \%$; A. actinomycetemcomitans 35 $\pm 17 \%)$. These results suggest that it is also possible to kill bacteria using red light, although the fluences used in the study were much higher than those used in most of the studies using blue light. In all cases, there was no antibacterial effect [53].

In contrast to the studies mentioned before, Izzo et al. assumed that killing of $P$. gingivalis was due to increasing temperatures, not due to a phototoxic effect. In this study, $P$. gingivalis was grown in a broth containing hemin and vitamin $\mathrm{K}$ [42]. For irradiation experiments, two different LEDs with peaks at wavelengths of $455 \pm 20$ or $625 \pm 20 \mathrm{~nm}$ were used. Tubes containing bacteria were irradiated with a total dose of $978 \mathrm{~J} / \mathrm{cm}^{3}(625 \pm 20 \mathrm{~nm})$ or $1.5 \mathrm{~kJ} / \mathrm{cm}^{3}(455 \pm 20 \mathrm{~nm})$ in a temperature-controlled shaker. Temperature during irradiation was $39-40^{\circ} \mathrm{C}$ for blue light and $41-42.5^{\circ} \mathrm{C}$ for red light. Consequently, the authors suggested that the increase of temperature was responsible for suppression of $P$. gingivalis and not a phototoxic effect due to excitation of endogenous PS. However, it has to be considered that these light doses were very high which may explain the observed temperature increases.

Overall, these results show that $P$. gingivalis was susceptible to blue- and red-light irradiation in most of the studies, although an antibacterial effect [53] was 
observed in only two studies [45,51] (Tables 1 \& 22). Inactivation rates for blue light were higher in general, but red-light irradiation could be particularly useful as it is known that light of longer wavelengths is able to penetrate tissues to a deeper extent [55].

\section{Prevotella spp.}

Imamura $e t$ al. investigated the effect of blue light on $P$. intermedia [41]. Irradiation was performed using a 405-nm monochromatic laser (300 s; 0.05-60 J). Inhibition rates were $40 \%$ for $15 \mathrm{~J}, \sim 70 \%$ for $30 \mathrm{~J}$ and $\sim 80 \%$ for 45 and $60 \mathrm{~J}$ (no antibacterial effect [53]). Inhibition of $P$. intermedia was similar to the results found for $P$. gingivalis, while there was no effect for suspensions of $E$. faecalis. There was no antibacterial effect [53] in any case.

Another group used planktonic $P$. intermedia, $P$. elanogenica and $P$. nigrescens grown anaerobically for their experiments (halogen lamp; $70 \mathrm{~mW} / \mathrm{cm}^{2}$; $\left.0-42 \mathrm{~J} / \mathrm{cm}^{2}\right)$ [52]. Irradiation for $1 \mathrm{~min}\left(4.2 \mathrm{~J} / \mathrm{cm}^{2}\right)$ resulted in an inactivation below detection limit for $P$. intermedia and P. nigrescens, while $P$. melanogenica was reduced by $70 \%$. Inactivation below detection limit of the latter was achieved by 5 min of irradiation $\left(21 \mathrm{~J} / \mathrm{cm}^{2}\right.$; antibacterial effect [53], Table 2). Survival fractions for $P$. gingivalis were $77.25 \%\left(4.2 \mathrm{~J} / \mathrm{cm}^{2}\right)$, $12.55 \%\left(21 \mathrm{~J} / \mathrm{cm}^{2}\right)$ and $1.48 \%\left(42 \mathrm{~J} / \mathrm{cm}^{2}\right)$, while there was no effect in the case of $S$. constellatus. HPLC analysis showed endogenous porphyrins in $P$. intermedia, $P$. nigrescens and $P$. melanogenica [52].

Hope et al. tested strains of $P$. intermedia and $P$. nigrescens [40]. Irradiation was performed using an $\operatorname{LED}\left(19.1 \mathrm{~mW} / \mathrm{cm}^{2}, \lambda=405 \mathrm{~nm}\right)$ and a laser pointer $\left(346.2 \mathrm{~mW} / \mathrm{cm}^{2}, \lambda=405 \mathrm{~nm}\right)$. Irradiation periods were $5-60 \mathrm{~s}$ for the laser $\left(1.7-20.8 \mathrm{~J} / \mathrm{cm}^{2}\right)$ and $10-300 \mathrm{~s}$ for the LED $\left(0.19-5.7 \mathrm{~J} / \mathrm{cm}^{2}\right)$. Control organisms $(E$. coli, Staphylococcus aureus, E. faecalis) were irradiated for $300 \mathrm{~s}$ using the LED $\left(5.7 \mathrm{~J} / \mathrm{cm}^{2}\right)$. Killing rates for $P$. nigrescens for the LED were $64.1 \%$ after $30 \mathrm{~s}$ and $94.26 \%$ after $300 \mathrm{~s}$. In the case of $P$. intermedia, even higher killing rates were observed using the LED (75.62\% after $10 \mathrm{~s}, 96.51 \%$ after $60 \mathrm{~s}, 99.75 \%$ after 300 s). Using the laser pointer, $99.56 \%$ of bacteria were killed after $5 \mathrm{~s}$ and $99.996 \%$ after $60 \mathrm{~s}$ (antibacterial effect [Lit], Table 2). Higher inactivation rates using the laser might be due to the much higher output power compared with the LED $\left(346.2 \mathrm{~mW} / \mathrm{cm}^{2}\right.$ as compared with $19.1 \mathrm{~mW} / \mathrm{cm}^{2}$ ). With respect to the control organisms, only in the case of $S$. aureus, a statistically significant antimicrobial effect could be observed $(36.73 \%$ after $300 \mathrm{~s}$, no antibacterial effect [53]).

Fontana et al. used different Prevotella spp. for their experiments $(P$. intermedia, $P$. melanogenica, $P$. nigrescens; LED; $\lambda=455 \mathrm{~nm} ; 80 \mathrm{~mW} / \mathrm{cm}^{2} ; 60 \mathrm{~s}$;
$4.8 \mathrm{~J} / \mathrm{cm}^{2}$ ) [32]. Survival fractions were $46.2 \%$ for P. ntermedia, $32.5 \%$ for P. nigrescens and $21.3 \%$ for $P$. melanogenica, respectively. The lowest survival rate was shown for F. nucleatum ss. polymorphum (6.4\%), while the highest survival rate was shown for $P$. gingivalis (79.7\%; no antibacterial effect [53] in any case). Additional examination of endogenous porphyrin production showed 80- to 200-times higher amounts for Prevotella spp. compared with Fusobacterium spp.

Henry et al. performed experiments using an argon laser $\left(\lambda=488-514 \mathrm{~nm} ; 20-200 \mathrm{~J} / \mathrm{cm}^{2}\right)$ for inactivation experiments of different Prevotella and Porphyromonas strains (please see Table 1 and Porphyromonas spp. chapter) [37,38].

König et al. evaluated the effect of red light on wildtype germs, isolated from patients with periodontal disease (helium-neon laser, $\lambda=632.8 \mathrm{~nm}, 360 \mathrm{~J} / \mathrm{cm}^{2}$ ) [44]. The killing rate for Prevotella spp. was determined to be $58 \pm 14 \%$ (no antibacterial effect [53]).

Overall, these results show that Prevotella spp. might be susceptible to irradiation with blue and red light, although no antibacterial effect [53] could be found in any of the studies. Visible light could be an adjunctive method in the treatment of diseases associated with the presence of these germs. As it was shown that inactivation might be possible using blue light and also red light, a combination of blue and red light could be useful for inactivation of Prevotella species as this combination would combine maximum bactericidal effect and maximum tissue penetration, which is known to be higher for light of longer wavelengths [55].

\section{Staphylococcus spp.}

de Sousa et al. investigated the effect of blue light emitted from a laser $(\lambda=450 \mathrm{~nm} ; 70 \mathrm{~mW})$ on strains of $S$. aureus [25]. Growth was inhibited at fluences higher than $6 \mathrm{~J} / \mathrm{cm}^{2}$ (reduction of $22 \%$ for $6 \mathrm{~J} / \mathrm{cm}^{2}$; no higher inhibition rates detected for 12,18 and $24 \mathrm{~J} / \mathrm{cm}^{2}$; no antibacterial effect [53] in any case). In general, inhibition of $S$. aureus was higher than inhibition observed for the control organisms Pseudomonas aeruginosa and E. coli.

Maclean et al. observed a significant bactericidal effect with a $5 \log _{10}$-step reduction (antibacterial effect [53]) upon illumination of $S$. aureus with a broadband xenon light source $\left(30 \mathrm{~min} ; 350 \mathrm{~mW} / \mathrm{cm}^{2}\right.$, $630 \mathrm{~J} / \mathrm{cm}^{2} ; 3 \log _{10}$ reduction for $420 \mathrm{~J} / \mathrm{cm}^{2}$ ) [48]. Further experiments showed no effects for wavelengths longer than $430 \mathrm{~nm}$, suggesting that only a small fraction within the wavelength range emitted by the broadband light source was responsible for inactivation. Maximum reduction in dependence of applied wavelength was observed at $405 \mathrm{~nm}$ at a fluence of $23.5 \mathrm{~J} / \mathrm{cm}^{2}\left(2.4 \log _{10}\right.$ steps $)$. Besides, they tested two 
different MRSA strains (a laboratory strain and a clinical strain obtained from a wound infection) for susceptibility under the same conditions. Results were similar to those obtained with $S$. aureus [48] (no detailed data presented). According to the study, there was an antibacterial effect [53] with the broadband xenon light for $420 \mathrm{~J} / \mathrm{cm}^{2}$. For E. coli, which was used as reference strain, there was no inactivation at all for irradiation up to $30 \mathrm{~min}$.

In another study by the same group, selected medical pathogens (please see Table 1) were illuminated with light from an arrow of LEDs $\left(10 \mathrm{~mW} / \mathrm{cm}^{2}\right)$ at a wavelength of $405 \mathrm{~nm}$ [49]. An approximately $5 \log _{10}{ }^{-}$ step reduction of CFU counts was achieved following exposure for $60-90 \mathrm{~min}\left(36-54 \mathrm{~J} / \mathrm{cm}^{2}\right)$. As a result of all the tested bacteria, they concluded that lower doses are sufficient for inactivation of Gram-positive bacteria, with the exception of $E$. faecalis, which was least susceptible to irradiation performed at $405 \mathrm{~nm}$. They concluded, that light emitted from an arrow of LEDs at $405 \mathrm{~nm}$ may be able to completely eradicate bacteria at high-population densities. For methicillin-suceptible S. aureus, $36 \mathrm{~J} / \mathrm{cm}^{2}$ was needed for a $5 \log _{10}$-step reduction, whereas $45 \mathrm{~J} / \mathrm{cm}^{2}$ was necessary in order to reach the same effect for MRSA (antibacterial effect [53]).

Using violet and blue light $(\lambda=405$ and $470 \mathrm{~nm})$ from superluminescent diodes at different fluences $\left(1-15 \mathrm{~J} / \mathrm{cm}^{2}\right)$, Guffey et al. observed nearly $90 \%$ of bacteria killing for $S$. aureus strains at a fluence of $15 \mathrm{~J} / \mathrm{cm}^{2}$ at $405 \mathrm{~nm}(160 \mathrm{~mW})$ [36]. 405-nm light killed $S$. aureus at all the tested fluences, whereas $470 \mathrm{~nm}(150 \mathrm{~mW})$ showed an effect at 10 and $15 \mathrm{~J} / \mathrm{cm}^{2}$ only exhibiting a $62 \%$ killing rate at $15 \mathrm{~J} / \mathrm{cm}^{2}$. Irradiation of $P$. aeruginosa resulted in higher inactivation rates at all doses $(95.1 \%$ maximum killing rate for $405 \mathrm{~nm}, 96.5 \%$ for $470 \mathrm{~nm}$ ), suggesting that $P$. aeruginosa might be slightly more susceptible (no antibacterial effect [53]) to violet- and blue-light irradiation. In contrast, no effect was reported upon irradiation of $P$. acnes, which is in contrast to several other in vitro and in vivo studies [56,57].

Kim et al. performed experiments using 425, 525 and $625 \mathrm{~nm}$ light on $P$. gingivalis, S. aureus and $E$. coli [43]. Results suggest that $425 \mathrm{~nm}$ as well as $525 \mathrm{~nm}$ light might be able to inactivate bacteria with higher susceptibility for $P$. gingivalis and $E$. coli compared with $S$. aureus (for details, please see Table 1 and Porphyromonas spp. chapter).

In another study, irradiation with different wavelengths from the visible and near-infrared spectrum $(660 \mathrm{~nm}$ red light, 830 and $904 \mathrm{~nm}$ near-infrared) emitted from a laser was tested for its effect in inhibiting growth of $S$. aureus. Inhibition of growth was observed for fluences higher than $12 \mathrm{~J} / \mathrm{cm}^{2}$ [27]. At a fluence of $24 \mathrm{~J} / \mathrm{cm}^{2}(660 \mathrm{~nm}$ red light; $30 \mathrm{~mW}$ output power), the inhibition rate was nearly $80 \%$ (no antibacterial effect [53]). Red light was more effective than infrared light. S. aureus was more susceptible to irradiation at all tested wavelength regardless of the applied fluence than $P$. aeruginosa and $E$. coli (no antibacterial [53] effect in any case).

Liposvky et al. tested two different strains of S. ureus for their susceptibility to visible light emitted from a halogen lamp $\left(300 \mathrm{~mW} / \mathrm{cm}^{2} ; 1,5,10 \mathrm{~min}\right.$; $18-180 \mathrm{~J} / \mathrm{cm}^{2}$ ), one methicillin-sensitive and one methicillin-resistant strain [46]. Results showed that the methicillin-sensitive strain was more susceptible to white light irradiation than the methicillin-resistant strain, with a maximum inactivation rate of $99.8 \%$ at a fluence of $180 \mathrm{~J} / \mathrm{cm}^{2}$ compared with $55.5 \%$ (no antibacterial effect [53] in any case). Measurements of hydroxyl and superoxide radical production in illuminated bacteria as well as porphyrin synthesis showed higher amounts for the methicillin-sensitive strain, whereas the resistant strain was able to adapt to oxidative stress to a higher extent. Carotinoid production was also measured, exhibiting higher values for the resistant strain. These findings may explain the higher susceptibility of the methicillin-sensitive strain to visible light irradiation.

Emwemeka et al. used a 470-nm SLD (superluminescent diode) phototherapy device $\left(30 \mathrm{~mW} / \mathrm{cm}^{2}\right.$; $1-60 \mathrm{~J} / \mathrm{cm}^{2}$ ) for experiments with two strains of MRSA [29]. At a fluence of $3 \mathrm{~J} / \mathrm{cm}^{2}$, nearly $30 \%$ inactivation was found for both strains. $55 \mathrm{~J} / \mathrm{cm}^{2}$ led to more than $90 \%$ killing rate for both strains (no antibacterial effect [53] in any case).

In another study performed by the same group, two strains of MRSA were irradiated with violet light [28]. As a light source, a cluster of 36 SLDs emitting light ranging from 390 to $420 \mathrm{~nm}$ with a $405-\mathrm{nm}$ peak was used (average power: $500 \mathrm{~mW}$; irradiance: $\left.100 \mathrm{~mW} / \mathrm{cm}^{2} ; 1-60 \mathrm{~J} / \mathrm{cm}^{2}\right)$. Maximum eradication was achieved applying light for 9.2 or 8.4 min with $55 \mathrm{~J} / \mathrm{cm}^{2}$ resulting in a killing rate of nearly $90 \%$ (no antibacterial effect [53] in any case).

The same group used MRSA spread on tryptic soy agar for irradiation experiments with a $470-\mathrm{nm}$ blue light-emitting LED $\left(30 \mathrm{~mW} / \mathrm{cm}^{2} ; 55-220 \mathrm{~J} / \mathrm{cm}^{2}\right)[21]$. $55 \mathrm{~J} / \mathrm{cm}^{2}$ resulted in $86-92 \%$ inactivation while $110 \mathrm{~J} / \mathrm{cm}^{2}$ and $220 \mathrm{~J} / \mathrm{cm}^{2}$ resulted in total suppression regardless of the cell concentration (antibacterial effect [53], Table 2).

Bumah et al. used an MRSA isolate for experiments with violet and blue light (405 and $470 \mathrm{~nm}$ ) [22]. Bacteria were spread on agar plates before irradiation. $100 \%$ of MRSA colonies at a concentration of $3 \times 10^{6}$ cells $/ \mathrm{ml}$ were suppressed by a single exposure to 55 or $60 \mathrm{~J} / \mathrm{cm}^{2}$ 
of 470-nm light; double exposure to 405-nm light with a 6 -h interval at 50,55 or $60 \mathrm{~J} / \mathrm{cm}^{2}$ showed the same result. Furthermore, this double treatment resulted in suppression of a cell density of $5 \times 10^{6} \mathrm{CFU} / \mathrm{ml}$, which was below detection limit (antibacterial effect [53]). $7 \times$ $10^{6} \mathrm{CFU} / \mathrm{ml}$ density in contrast had to be illuminated either once with $220 \mathrm{~J} / \mathrm{cm}^{2}$ of $470-\mathrm{nm}$ blue light or twice with $220 \mathrm{~J} / \mathrm{cm}^{2}$ using $405-\mathrm{nm}$ blue light in order to achieve the same effect. The authors concluded that repeated illumination may be necessary for complete eradication of denser bacterial concentrations, especially when applying lower fluences (Tables 1 \& 2).

Masson-Meyers et al. compared the effect of 405-nm blue light emitted from an LED $\left(100 \mathrm{~mW} / \mathrm{cm}^{2}\right)$ with blue light emitted from a laser $\left(135 \mathrm{~mW} / \mathrm{cm}^{2}\right)$ on MRSA $\left(5 \times 10^{6}\right.$ cells $\left./ \mathrm{ml}\right)$ [50]. Irradiation was performed once, twice or thrice with either light from the LED or from the laser at fluences of $40,54,81$ or $121 \mathrm{~J} / \mathrm{cm}^{2}$. Time intervals in between were 15,30 or $240 \mathrm{~min}$. Results showed significant growth suppression for each fluence for both light sources with no 'statistical difference' for LED and laser 'in 35 of the 36 experimental samples' [50]. Irradiation in two or three intervals increased bacterial suppression, especially when the treatment interval was 15 or $30 \mathrm{~min} .54 \mathrm{~J} / \mathrm{cm}^{2}$ triple irradiation with laser (intervals of $15 \mathrm{~min}$ ) resulted in suppression, which was below detection limit (antibacterial effect [53], Table 2).

Testing susceptibility of monolayer biofilms formed by different bacteria on glass surfaces, McKenzie et al. performed irradiation for 5, 10 and 20 min using a 405-nm LED $\left(141.48 \mathrm{~mW} / \mathrm{cm}^{2}\right)$ [47]. Inactivation rates for $S$. aureus were $0.61,1.87,2.75 \log _{10}$ steps for 5,10 and $20 \mathrm{~min}\left(0.7,1.4,2.8 \mathrm{~J} / \mathrm{cm}^{2}\right)$, respectively (no antibacterial effect [53]). Most rapid and effective inactivation was observed for $E$. coli monolayer biofilms with a $2.52 \log _{10}$-step reduction upon $10 \mathrm{~min}$ of exposure to light, and $3.55 \log _{10}$-step reduction following $20 \mathrm{~min}$ of exposure (antibacterial effect [53]). In the case of mixed-species biofilms formed by strains of $S$. aureus and E. coli, a $2.19 \log _{10}$-step reduction (total viable counts) after $30 \mathrm{~min}$ of irradiation was achieved.

Ghate $e$ al. tested the antibacterial effect of LEDs emitting light in the visible region $(7.5 \mathrm{~h} ; 461 \mathrm{~nm}$, $16 \mathrm{~mW} / \mathrm{cm}^{2}, 432 \mathrm{~J} / \mathrm{cm}^{2} ; 521 \mathrm{~nm}, 22,1 \mathrm{~mW} / \mathrm{cm}^{2}$, $\left.557 \mathrm{~J} / \mathrm{cm}^{2} ; 642 \mathrm{~nm}, 25,4 \mathrm{~mW} / \mathrm{cm}^{2}, 640 \mathrm{~J} / \mathrm{cm}^{2}\right)$ on $S$. aureus as well as selected foodborne pathogens (E. coli, S. typhimurium, L. monocytogens) [34]. Irradiance was performed at three different temperatures $(20,15$ and $\left.10^{\circ} \mathrm{C}\right)$. An approximately $5 \log _{10}$-step inactivation (antibacterial effect [53]) for all the tested strains was observed using $461-\mathrm{nm}$ light at 10 and $15^{\circ} \mathrm{C}$, while inactivation rates for $521 \mathrm{~nm}$ light were $1-2 \log _{10}$ steps only and there was no antibacterial effect [53] for 642-nm light. In general, inactivation rates were higher at 10 and $15^{\circ} \mathrm{C}$ compared with $20^{\circ} \mathrm{C}$.

It can be concluded that Staphylococcus spp. may be susceptible to visible light irradiation to a certain extent. Especially in the case of strains resistant to common antibiotics (MRSA), this might be a useful additional treatment modality.

\section{Streptococcus spp.}

Maclean et al. used high-intensity 405-nm light from an LED $\left(10 \mathrm{~mW} / \mathrm{cm}^{2}\right)$ for irradiation of different Gram-positive and Gram-negative bacteria [49]. Highest inactivation rates were measured for Streptococcus, Staphylococcus and Clostridium spp. ( $\sim 5$ $\log _{10}$-step reduction following irradiations for 60 and $90 \mathrm{~min}$ corresponding to fluences of 36 and $54 \mathrm{~J} / \mathrm{cm}^{2}$; antibacterial effect [53]).

Soukos et al. used strains of $S$. constellatus for their experiments [52]. For illumination of planktonic cultures, a halogen lamp $\left(\lambda=380-520 \mathrm{~nm}, 70 \mathrm{~mW} / \mathrm{cm}^{2}\right.$, $0-42 \mathrm{~J} / \mathrm{cm}^{2}$ ) was used. There was no effect for visible light irradiation for $S$. constellatus.

Feuerstein et al. compared susceptibility of planktonic cultures of $P$. gingivalis, $F$. nucleatum, S. mutans and E. faecalis to blue light emitted from halogen lamps with filters (400-500 nm; 260-416 mW/ $/ \mathrm{cm}^{2}$ ), a filtered xenon light source (plasma arc: $450-490 \mathrm{~nm} ; 1144 \mathrm{~mW} / \mathrm{cm}^{2}$ ) and an LED (450-480 nm; $\left.520 \mathrm{~mW} / \mathrm{cm}^{2}\right)$ [31]. As a result, bactericidal effects for $P$. gingivalis and $F$. nucleatum could be observed only, whereas there was no effect for $S$. mutans and $S$. faecalis under the same conditions (Table 1; no antibacterial effect [53]).

Examination of viability and structure of biofilms of $S$. mutans formed after exposure to bluelight irradiation for $1-10 \mathrm{~min}(400-500 \mathrm{~nm}$; $1.13 \mathrm{~W} / \mathrm{cm}^{2} ; 68-680 \mathrm{~J} / \mathrm{cm}^{2}$ ) was investigated by Chebath-Taub et al. [23]. Illuminated biofilms were dispersed and reorganization as a new biofilm was examined at different time intervals by viable counts and confocal laser scanning microscopy (LIVE/DEAD staining). As a result, a significant decrease in bacterial viability was found after $6 \mathrm{~h}$ of reorganization (up to $80 \%$ when irradiated for 10 min before reorganization, no antibacterial effect [53]). Besides, the amount of dead bacteria increased compared with the situation before irradiation, suggesting that blue light might have a delayed antibacterial influence although there was no effect upon capability of reforming new biofilm.

In a subsequent study, this group performed further tests concerning the pathogenicity of the new formed biofilms (LED light-curing unit; $\lambda=$ $460-480 \mathrm{~nm} ; 620 \mathrm{~mW} / \mathrm{cm}^{2} ; 1,3,7 \mathrm{~min} ; 37,112$ and $262 \mathrm{~J} / \mathrm{cm}^{2}$ ) [24]. Quantification of bacteria was 
achieved by measurement of the optical density and quantitative polymerase chain reaction (quantification of DNA samples of $S$. mutans); furthermore, confocal laser scanning microscopy was used for determination of bacterial viability and extracellular polysaccharide (EPS) production; quantitative polymerase chain reaction was also used for determination of acidogenicity and acidurity of bacteria. Although bacterial total growth increased in regrown biofilms, amount of dead bacteria outweighed while polysaccharide production decreased. Regrown biofilms after illumination showed less acidogenicity as well as lower aciduricity. According to these results, blue light may be a proper treatment tool for reducing pathogenicity of bacteria dispersed from the biofilm-colonizing new surfaces. It may not be possible to completely kill bacteria organized in a biofilm structure, but it may be possible to diminish the pathogenicity of biofilms by means of visible light irradiation.

In another study, Gomez et al. irradiated initial biofilms ( $\lambda=380-440 \mathrm{~nm}$ with $405-\mathrm{nm}$ peak) formed by strains of $S$. mutans grown for 12-16 h [35]. Intensity on surface was $13 \mathrm{~mW} / \mathrm{cm}^{2}$ and irradiation was done for $5 \mathrm{~min}$, resulting in a fluence of $9.26 \mathrm{~J} / \mathrm{cm}^{2}$. Biofilms were grown either in Tryptic Soy Broth (TSB) or in TSB containing 1\% sucrose. Percentage of bacteria killed was $70 \%$ in the case of biofilm grown in TSB and $50 \%$ in the case of biofilm grown in TSB containing $1 \%$ sucrose suggesting that addition of sucrose leads to more resistant biofilms (no antibacterial effect [53]). These results show that killing of bacteria not only depends on the microorganism by itself but also on other factors such as nutrition.

In another study, bacteria were exposed to red light emitted from a helium-neon laser $(60 \mathrm{~mW}$ helium-neon laser; $632.8 \mathrm{~nm}$; total energy density: $360 \mathrm{~J} / \mathrm{cm}^{2}$ ) [44]. While there were bactericidal effects on $A$. odontolyticus, $P$. acnes and $P$. gingivalis, there was no effect on S. mutans (no antibacterial effect [53] in any case).

Aim of another work was to examine twice-daily visible light irradiation on development of matrixrich biofilms [26]. S. mutans biofilms were grown for 5 days. Irradiation was performed two-times a day using a noncoherent blue-light source $(420-\mathrm{nm}$ blue light; $92 \mathrm{~mW} / \mathrm{cm}^{2} ; 12 \mathrm{~min} 56 \mathrm{~s} ; 72 \mathrm{~J} / \mathrm{cm}^{2}$ ). Bacterial viability, dry weight and intracellular polysaccharide (IPS) and EPS were measured. Twice-daily treatment with $0.12 \%$ chlorhexidine served as positive control, while $\mathrm{NaCl}$ treatment served as negative control (1 min, respectively). CFUs were reduced to the highest amount in the chlorhexidine group (around $4 \log _{10}$ steps, antibacterial effect [53], Table 2), while there was only minimal reduction when irradiated with blue light $\left(\sim 1 \log _{10}\right.$ step; no antibacterial effect [53]). Reduction of insoluble EPS was highly affected by twice-daily bluelight irradiation, suggesting that this might be a proper treatment modality in prevention of biofilm development as insoluble EPS is forming the scaffold of the extracellular biofilm matrix.

Overall, the results obtained for visible light irradiation of Streptococcus spp. suggest that eradication, especially in biofilm state, might be difficult to achieve, but visible light could be a promising modality for influencing biofilm architecture in order to lower pathogenicity, aciduricity and acidogenicity.

\section{Discussion \& conclusion}

Visible light irradiation is already regularly applied in clinical dermatological practice for topical treatment of acne vulgaris [56,57] or infected wounds [58]. Furthermore, visible light application is discussed as a treatment option for patients with gastric diseases mainly caused by Helicobacter pylori, where traditional treatment modalities often lead to failure [59,60]. The aim of this study was to summarize studies dealing with in vitro inactivation of bacteria occurring in the oral cavity in order to estimate the potential of visible light for inactivation of oral diseases associated with bacteria.

As a result, it can be concluded that eradication of bacteria in planktonic cultures by means of visible light seems possible, especially in case of black-pigmented bacteria such as Porphyromonas and Prevotella spp. With regard to bacteria organized in biofilms, reported evidence is less clear. Considering the reviewed studies, it seems as if inactivation is hampered when bacteria are embedded in a biofilm structure. This has to be taken into consideration as biofilm accumulation is the most common situation in the oral cavity as well as in nature [61]. It is well known that biofilms show higher resistances to distinct antibacterial agents [62]. In this instance, the biofilm matrix has been identified as a possible barrier for penetration of antibacterial agents [63]. If an antibacterial effect [53] is required, for example, for endodontic issues [64], additional application of an exogenous PS may result in higher inactivation rates $[65,66]$. Thereby, the antimicrobial effect of the light source itself should be seen as an additional effect resulting in higher inactivation rates. In this respect, light offers a synergistic effect to the PS. If light of distrinct wavelengths without PS is used for bacterial inactivation high levels of energy are required, which may result in potential tissue damage [67]. In light of this, a novel light source emitting visible light + waterfiltered infrared-A is potentially beneficial, particularly in combination with a PS, for treatment of topical biofilm infections [68], as water-filtered infrared-A is also known for its wound healing properties [69]. 


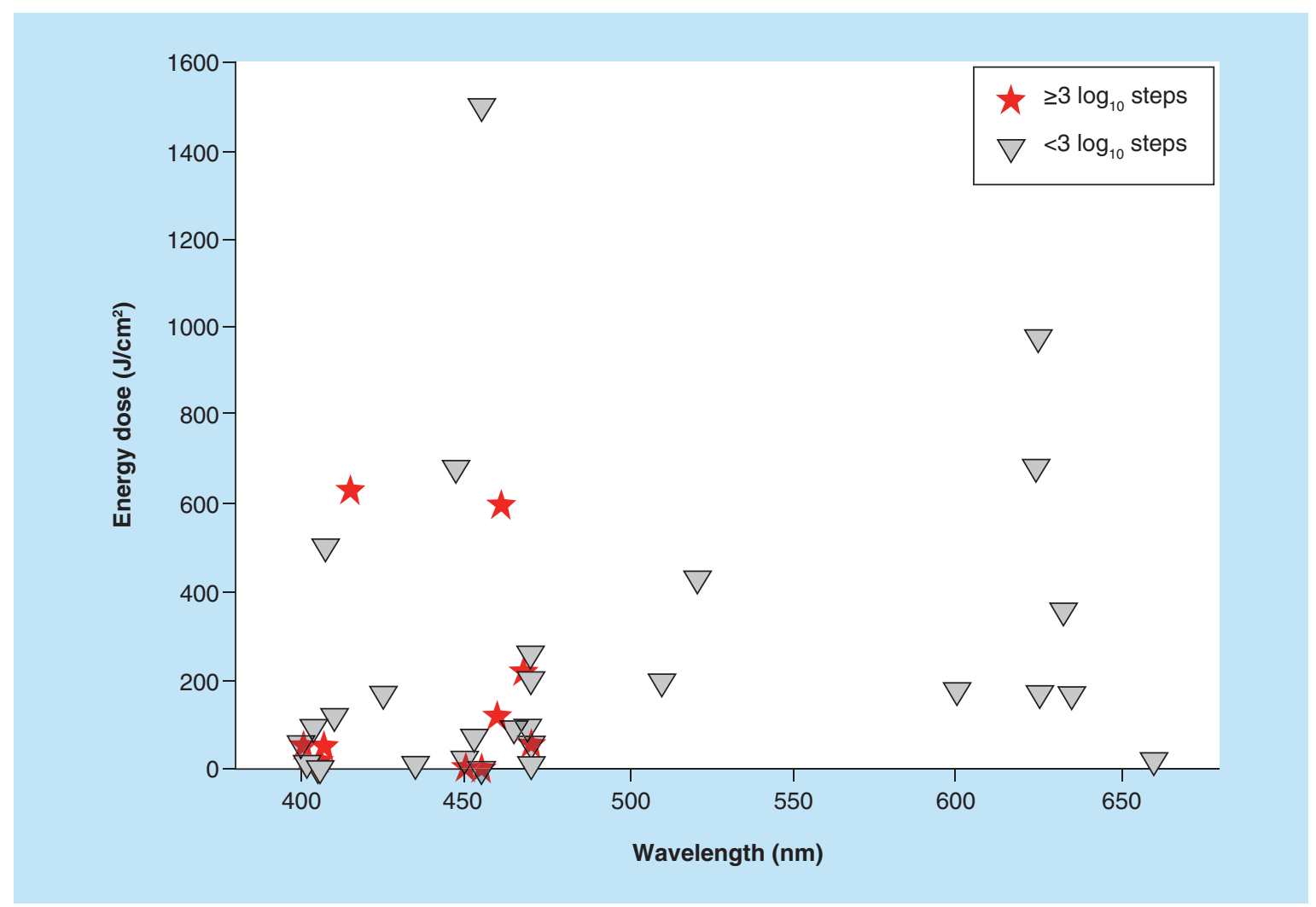

Figure 2. Wavelengths used for inactivation as well as corresponding maximum energy dose or energy dose required for an inactivation $\geq 3 \log _{10}$ steps (asterisk) and $<3 \log _{10}$ steps (triangle) are shown (planktonic bacteria). For wavelength, peak showing maximum output power of the light source is shown whenever spectral characteristics were known, otherwise median wavelengths are shown. Further details are shown in Supplementary Table 1.

Considering effectiveness of light of different wavelengths, there seems to be an overlap of emission spectra with absorption spectra of different classes of porphyrins [70,71]. This is in accordance with different reviewed studies which showed high amounts of endogenous porphyrins for different bacteria [11,32-33].

In contrast, for prophylactic issues illumination with visible light without an exogenous PS may be a useful tool by controlling pathogenicity of biofilms [32]. The great advantage of visible light consists in the possibility of repetitive treatments as there are no major side effects as compared with UV light, for example [14]. Besides, application of light without preincubation with an exogenous PS is a treatment modality that may even be conducted by a patient by his or her own due to its ease in handling. For being able to draw a conclusion on the potential of this modality, further in vitro studies are necessary that investigate the influence of visible light irradiation on biofilms, for example, formed in vitro by cariogenic or periodontal key pathogens or on biofilms ex vivo.

Visible light could be a promising treatment option for periodontal disease, where black pigmented bacteria play a crucial role [72]. By selectively killing black-pigmented bacteria, it could be possible to lower pathogenicity of a periodontal biofilm without harming beneficial bacteria resulting in a healthy equilibrium [52].

It has to be considered, though, that the energy doses and irradiation times applied in some studies are beyond practicability, lowering the value of the received results. Using high-energy doses, it is sometimes not clear whether inactivation occurs due to light-mediated effects or due to heat-induced effects.

As there is a great variation in the energy doses applied in the studies included in this review, comparison of the obtained results is seriously hampered (compare Tables 1 \& 2). Therefore, for further studies, it is a crucial point to take the characteristics of the employed light sources into account. Proper comparison of antibacterial properties of light of distinct wavelengths on microorganisms will only be possible, if specific characteristics of the light source, like wavelength, emission spectrum and fluence are taken into consideration. In this regard, it has recently been shown by our group in the case of photodynamic inactivation in presence of an exogenous PS that this should be considered for 
comparing antibacterial activity with different PSs and light of different wavelengths [73]. It could be useful to establish a similar formula for comparison of phototoxic effect of distinct bacteria by illumination with light without addition of an exogenous PS.

Another point is that culture conditions of the bacteria investigated in the studies considered are highly variable, too. It is well known that production of endogenous porphyrins is highly depending of the respective culture conditions (e.g., addition of precursors in porphyrin-synthesis like hemin and vitamin K) [74] .

Overall, the results reviewed in this paper imply that visible light could be a treatment option for oral diseases. However, further studies especially concerning the situation in biofilm state are necessary, before clinical studies can be conducted for a final assessment of effectiveness of visible light irradiation for treatment of oral diseases.

\section{Future perspective}

Application of visible light may be a promising tool for control of oral bacterial infections, especially considering prophylactic issues. As already concluded before, further studies especially dealing the situation in a biofilm state are required.

Considering the situation with addition of an exogenous light-sensitive substance, the toxicity of the light itself has to be seen as an additional improvement for in vivo use. Therefore, it seems appropriate for development of new light-sensitive substances to use light of a wavelength that shows antimicrobial effects in order to further enhance the effect.

\section{Financial \& competing interests disclosure}

This study was funded in part by a grant of the Deutsche Forschungsgemeinschaft (German Research Foundation; Cl 263/1-1). The authors have no other relevant affiliations or financial involvement with any organization or entity with a financial interest in or financial conflict with the subject matter or materials discussed in the manuscript apart from those disclosed.

No writing assistance was utilized in the production of this manuscript.

\section{Executive summary}

- Inactivation of bacteria in planktonic state shows promising results.

- There is less evidence considering situation in a biofilm; inactivation using visible light seems less effective when bacteria are organized as a biofilm.

- Inactivation may be due to endogenous porphyrins produced during bacterial metabolism.

- Use of visible light should be taken into consideration, especially for routine use in prophylactic issues.

\section{References}

Papers of special note have been highlighted as: $\bullet$ of interest;

• of considerable interest

1 Sir Alexander Flemming. Sir Alexander Fleming - Nobel lecture: penicillin.

www.nobelprize.org/nobel_prizes/medicine/laureates/1945/

2 World Health Organization. Antimicrobial resistance. www.who.int/mediacentre/factsheets/fs194/en/

3 Centers for Disease Control and Prevention. Notes from the field: pan-resistant New Delhi metallo-beta-lactamaseproducing Klebsiella pneumoniae - Washoe County, Nevada, 2016 | MMWR.

www.cdc.gov/mmwr/volumes/66/wr/mm6601a7.htm?s

4 Bidault P, Chandad F, Grenier D. Risk of bacterial resistance associated with systemic antibiotic therapy in periodontology. J. Can. Dent. Assoc. 73(8), 721-725 (2007).

5 Al-Ahmad A, Ameen H, Pelz K et al. Antibiotic resistance and capacity for biofilm formation of different bacteria isolated from endodontic infections associated with root-filled teeth. J. Endod. 40(2), 223-230 (2014).

6 Dai T, Huang Y, Hamblin MR. Photodynamic therapy for localized infections--state of the art. Photodiag. Photodyn. Ther. 6(3-4), 170-188 (2009).
7 St Denis TG, Dai T, Izikson L et al. All you need is light: antimicrobial photoinactivation as an evolving and emerging discovery strategy against infectious disease. Virulence 2(6), 509-520 (2011).

8 Wainwright M. Photodynamic antimicrobial chemotherapy (PACT). J. Anti Chemo 42(1), 13-28 (1998).

9 Cieplik F, Tabenski L, Buchalla W, Maisch T. Antimicrobial photodynamic therapy for inactivation of biofilms formed by oral key pathogens. Front. Microbiol. 5, 405 (2014).

- Review of interest for summarizing inactivation of oral biofilms with visible light + photosensitizer.

10 Lipovsky A, Nitzan Y, Gedanken A, Lubart R. Visible light-induced killing of bacteria as a function of wavelength: implication for wound healing. Las. Surg. Med. 42(6), 467-472 (2010).

11 Cieplik F, Spath A, Leibl C et al. Blue light kills Aggregatibacter actinomycetemcomitans due to its endogenous photosensitizers. Clin. Oral Investig. 18(7), 1763-1769 (2014).

12 Hessling M, Spellerberg B, Hoenes K. Photoinactivation of bacteria by endogenous photosensitizers and exposure to visible light of different wavelengths - a review on existing data. FEMS Microbiol. Lett. 364(2), fnw270 (2016). 
13 Centers for Disease Control and Prevention. CDC - disinfection \& sterilization guideline: misc agents HICPAC. www.cdc.gov/hicpac/Disinfection_

14 McMillan TJ, Leatherman E, Ridley A, Shorrocks J, Tobi SE, Whiteside JR. Cellular effects of long wavelength UV light (UVA) in mammalian cells. J. Pharm. Pharmacol. 60 (8), 969-976 (2008).

15 Rastogi RP, Richa, Kumar A, Tyagi MB, Sinha RP. Molecular mechanisms of ultraviolet radiation-induced DNA damage and repair. J. Nucleic Acids 2010, 592980 (2010).

16 Centers for Disease Control and Prevention. CDC - what is skin cancer? www.cdc.gov/cancer/skin/basic_info/what-is-skin-cancer.

17 National Aeronautics and Space Administration. What wavelength goes with a color? https://science-edu.larc.nasa.gov/EDDOCS/Wavelengths

18 McGowan J, Sampson M, Lefebvre C. An evidence based checklist for the peer review of electronic search strategies (PRESS EBC). Evid. Based Libr. Inf. Pract. 5(1), 149-154 (2010).

19 Atkinson KM, Koenka AC, Sanchez CE, Moshontz H, Cooper H. Reporting standards for literature searches and report inclusion criteria: making research syntheses more transparent and easy to replicate. Res. Syn. Meth. 6(1), 87-95 (2015).

20 Bramer WM, Giustini D, Jonge GB, Holland L, Bekhuis T. De-duplication of database search results for systematic reviews in EndNote. J. Med. Lib. Ass. 104(3), 240-243 (2016).

21 Bumah VV, Masson-Meyers DS, Enwemeka CS. Blue $470 \mathrm{~nm}$ light suppresses the growth of Salmonella enterica and methicillin-resistant Staphylococcus aureus (MRSA) in vitro. Las. Surg. Med. doi:10.1002/1sm.22385 (2015) (Epub ahead of print).

22 Bumah VV, Masson-Meyers DS, Cashin S, Enwemeka CS. Optimization of the antimicrobial effect of blue light on methicillin-resistant Staphylococcus aureus (MRSA) in vitro. Las. Surg. Med. 47(3), 266-272 (2015).

23 Chebath-Taub D, Steinberg D, Featherstone JDB, Feuerstein O. Influence of blue light on Streptococcus mutans reorganization in biofilm. J. Photochem. Photobiol. B. 116, 75-78 (2012).

24 Cohen-Berneron J, Steinberg D, Featherstone JDB, Feuerstein O. Sustained effects of blue light on Streptococcus mutans in regrown biofilm. Las. Med. Sci. 31(3), 445-452 (2016).

25 de Sousa NTA, Santos MF, Gomes RC, Brandino HE, Martinez R, de Jesus Guirro RR. Blue laser inhibits bacterial growth of Staphylococcus aureus, Escherichia coli, and Pseudomonas aeruginosa. Photomed. Laser Surg. 33(5), 278-282 (2015).

26 de Sousa DL, Lima RA, Zanin IC, Klein MI, Janal MN, Duarte $S$. Effect of twice-daily blue light treatment on matrix-rich biofilm development. PLoS ONE 10(7), e0131941 (2015).
- $\quad$ For examining effect of blue light on biofilm matrix.

27 de Sousa NTA, Gomes RC, Santos MF, Brandino HE, Martinez R, de Jesus Guirro RR. Red and infrared laser therapy inhibits in vitro growth of major bacterial species that commonly colonize skin ulcers. Las. Med. Sci. 31(3), 549-556 (2016).

28 Enwemeka CS, Williams D, Hollosi S, Yens D, Enwemeka SK. Visible $405 \mathrm{~nm}$ SLD light photo-destroys methicillinresistant Staphylococcus aureus (MRSA) in vitro. Las. Surg. Med. 40 (10), 734-737 (2008).

29 Enwemeka CS, Williams D, Enwemeka SK, Hollosi S, Yens D. Blue 470-nm light kills methicillin-resistant Staphylococcus aureus (MRSA) in vitro. Photomed. Laser Surg. 27(2), 221-226 (2009).

30 Feuerstein O, Ginsburg I, Dayan E, Veler D, Weiss EI. Mechanism of visible light phototoxicity on Porphyromonas gingivalis and Fusobacterium nucleatum. Photochem. Photobiol. 81(5), 1186-1189 (2005).

31 Feuerstein O, Persman N, Weiss EI. Phototoxic effect of visible light on Porphyromonas gingivalis and Fusobacterium nucleatum: an in vitro study. Photochem. Photobiol. 80(3), 412-415 (2004).

32 Fontana CR, Song X, Polymeri A, Goodson JM, Wang X, Soukos NS. The effect of blue light on periodontal biofilm growth in vitro. Las. Med. Sci. 30(8), 2077-2086 (2015).

33 Fukui M, Yoshioka M, Satomura K, Nakanishi H, Nagayama M. Specific-wavelength visible light irradiation inhibits bacterial growth of $\mathcal{P} \quad s t \quad v$ st. J. Periodontal. Res. 43(2), 174-178 (2008).

34 Ghate VS, Ng KS, Zhou W et al. Antibacterial effect of light emitting diodes of visible wavelengths on selected foodborne pathogens at different illumination temperatures. Int. J. Food Microbiol. 166(3), 399-406 (2013).

35 Gomez GF, Huang R, MacPherson M, Ferreira Zandona AG, Gregory RL. Photo inactivation of Streptococcus mutans biofilm by violet-blue light. Curr. Microbiol. 73(3), 426-433 (2016).

36 Guffey JS, Wilborn J. In vitro bactericidal effects of 405$\mathrm{nm}$ and 470-nm blue light. Photomed. Laser Surg. 24(6), 684-688 (2006).

37 Henry CA, Judy M, Dyer B, Wagner M, Matthews JL. Sensitivity of Porphyromonas and Prevotella species in liquid media to argon laser. Photochem. Photobiol. 61(4), 410-413 (1995).

38 Henry CA, Dyer B, Wagner M, Judy M, Matthews JL. Phototoxicity of argon laser irradiation on biofilms of Porphyromonas and Prevotella species. J. Photochem. Photobiol. B. 34(2-3), 123-128 (1996).

39 Hope CK, Hindley JA, Khan Z, de Jong EJ, Higham SM. Lethal photosensitization of Porphyromonas gingivalis by their endogenous porphyrins under anaerobic conditions: an in vitro study. Photodiag. Photodyn. Ther. 10(4), 677-682 (2013).

40 Hope CK, Strother M, Creber HK, Higham SM. Lethal photosensitisation of Prevotellaceae under anaerobic conditions by their endogenous porphyrins. Photodiag. Photodyn. Ther. 13, 344-346 (2016). 
41 Imamura T, Tatehara S, Takebe Y et al. Antibacterial and antifungal effect of $405 \mathrm{~nm}$ monochromatic laser on endodontopathogenic microorganisms. Inter. Jou. Phot. 2014(5), 1-7 (2014).

42 Izzo AD, Walsh JT. Light-induced modulation of Porphyromonas gingivalis growth. J. Photochem. Photobiol. B. 77(1-3), 63-69 (2004).

$43 \mathrm{Kim}$ S, Kim J, Lim W et al. In vitro bactericidal effects of 625,525 , and $425 \mathrm{~nm}$ wavelength (red, green, and blue) light-emitting diode irradiation. Photomed. Laser Surg. 31(11), 554-562 (2013).

44 König K, Teschke M, Sigusch B, Glockmann E, Eick S, Pfister W. Red light kills bacteria via photodynamic action. Cell. Mol. Biol. (Noisy-le-grand) 46(7), 1297-1303 (2000).

45 Kotoku Y, Kato J, Akashi G, Hirai Y, Ishihara K. Bactericidal effect of a 405-nm diode laser on Porphyromonas gingivalis. Las. Phys. Lett. 6(5), 388-392 (2009).

46 Lipovsky A, Nitzan Y, Friedmann H, Lubart R. Sensitivity of Staphylococcus aureus strains to broadband visible light. Photochem. Photobiol. 85(1), 255-260 (2009).

47 McKenzie K, Maclean M, Timoshkin IV, Endarko E, MacGregor SJ, Anderson JG. Photoinactivation of bacteria attached to glass and acrylic surfaces by $405 \mathrm{~nm}$ light: potential application for biofilm decontamination. Photochem. Photobiol. 89(4), 927-935 (2013).

48 Maclean M, MacGregor SJ, Anderson JG, Woolsey G. Highintensity narrow-spectrum light inactivation and wavelength sensitivity of Staphylococcus aureus. FEMS Microbiol. Lett. 285(2), 227-232 (2008).

49 Maclean M, MacGregor SJ, Anderson JG, Woolsey G. Inactivation of bacterial pathogens following exposure to light from a 405-nanometer light-emitting diode array. Appl. Environ. Microbiol. 75(7), 1932-1937 (2009).

50 Masson-Meyers DS, Bumah VV, Biener G, Raicu V, Enwemeka CS. The relative antimicrobial effect of blue $405 \mathrm{~nm}$ LED and blue $405 \mathrm{~nm}$ laser on methicillin-resistant Staphylococcus aureus in vitro. Las. Med. Sci. 30(9), 2265-2271 (2015).

51 Song H, Lee J, Um H, Chang B, Lee S, Lee M. Phototoxic effect of blue light on the planktonic and biofilm state of anaerobic periodontal pathogens. J. Periodontal. Implant. Sci. 43(2), 72-78 (2013).

52 Soukos NS, Som S, Abernethy AD et al. Phototargeting oral black-pigmented bacteria. Antimicrob. Agents Chemother. 49(4), 1391-1396 (2005).

53 Boyce JM, Pittet D. Guideline for hand hygiene in healthcare settings. Recommendations of the Healthcare Infection Control Practices Advisory Committee and the HICPAC/ SHEA/APIC/IDSA Hand Hygiene Task Force. Society for Healthcare Epidemiology of America/Association for Professionals in Infection Control/Infectious Diseases Society of America. MMWR Recomm. Rep. 51(RR-16), 1-45, quiz CE1-4 (2002).

54 Liberati A, Altman DG, Tetzlaff J et al. The PRISMA statement for reporting systematic reviews and meta-analyses of studies that evaluate health care interventions: explanation and elaboration. PLoS Med. 6(7), e1000100 (2009).
55 Hirmer M, Danilov SN, Giglberger S et al. Spectroscopic study of human teeth and blood from visible to terahertz frequencies for clinical diagnosis of dental pulp vitality. J. Infra. Milli. Terahz. Waves 33(3), 366-375 (2012).

-• For examining spectral characteristics of human teeth.

56 Elman M, Slatkine M, Harth Y. The effective treatment of acne vulgaris by a high-intensity, narrow band $405-420 \mathrm{~nm}$ light source. J. Cosmet. Las. Ther. 5(2), 111-117 (2009).

57 Gold MH, Sensing W, Biron JA. Clinical efficacy of homeuse blue-light therapy for mild-to moderate acne. J. Cosmet. Las. Ther. 13(6), 308-314 (2011).

58 Lipovsky A, Nitzan Y, Lubart R. A possible mechanism for visible light-induced wound healing. Las. Surg. Med. 40 (7), 509-514 (2008).

59 Lembo AJ, Ganz RA, Sheth S et al. Treatment of Helicobacter pylori infection with intra-gastric violet light phototherapy: a pilot clinical trial. Las. Surg. Med. 41(5), 337-344 (2009).

-• For describing the possibility of intragastric light application for inactivation of Helicobacter pylori.

60 Ganz RA, Viveiros J, Ahmad A et al. Helicobacter pylori in patients can be killed by visible light. Las. Surg. Med. 36(4), 260-265 (2005).

61 Davey ME, O’Toole GA. Microbial biofilms: from ecology to molecular genetics. Microbiol. Mol. Biol. Rev. 64(4), 847-867 (2000).

62 Davies D. Understanding biofilm resistance to antibacterial agents. Nat. Rev. Drug Discov. 2(2), 114-122 (2003).

63 Tseng BS, Zhang W, Harrison JJ et al. The extracellular matrix protects Pseudomonas aeruginosa biofilms by limiting the penetration of tobramycin. Environ. Microbiol. 15(10), 2865-2878 (2013).

64 Barnett F, Siqueira JF. Instrumentation and disinfection of root canals. In: Endodontic Prognosis: Clinical Guide for Optimal Treatment Outcome. Chugal N, Lin LM (Eds). Springer Verlag, Cham, Switzerland, 131-140 (2016).

65 Cieplik F, Spath A, Regensburger J et al. Photodynamic biofilm inactivation by SAPYR - an exclusive singlet oxygen photosensitizer. Free Radic. Biol. Med. 65, 477-487 (2013).

66 Komerik N, Nakanishi H, MacRobert AJ, Henderson B, Speight P, Wilson M. In vivo killing of Porphyromonas gingivalis by toluidine blue-mediated photosensitization in an animal model. Antimicrob. Agents Chemother. 47(3), 932-940 (2003).

67 Spranley TJ, Winkler M, Dagate J, Oncale D, Strother E. Curing light burns. Gen. Dent. 60(4), e210-e214 (2012).

68 Al-Ahmad A, Bucher M, Anderson AC et al. Antimicrobial photoinactivation using visible light plus water-filtered infrared-A (VIS + wIRA) alters in situ oral biofilms. PLoS ONE 10(7), e0132107 (2015).

- $\quad$ For examining influence of visible light plus water-filtered infrared-A on biofilm in situ.

69 Hoffmann G, Hartel M, Mercer JB. Heat for wounds - water-filtered infrared-A (wIRA) for wound healing a review. Ger. Med. Sci. 14, Doc08 (2016).

70 Lan M, Zhao H, Yuan H, Jiang C, Zuo S, Jiang Y. Absorption and EPR spectra of some porphyrins and metalloporphyrins. Dyes and Pigments 74(2), 357-362 (2007). 
71 Stojiljkovic I, Evavold BD, Kumar V. Antimicrobial properties of porphyrins. Expert Opin. Investig. Drugs 10(2), 309-320 (2001).

72 van Steenbergen TJM, van Winkelhoff AJ, de Graaff J, van der Velden U. Taxonomy, virulence and epidemiology of black-pigmented bacteroides species in relation to oral infections. Infection 17(3), 194-196 (1989).
73 Cieplik F, Pummer A, Regensburger J et al. The impact of absorbed photons on antimicrobial photodynamic efficacy. Front. Microbiol. 6, 706 (2015).

74 Fyrestam J, Bjurshammar N, Paulsson E, Mansouri $\mathrm{N}$, Johannsen A, Östman C. Influence of culture conditions on porphyrin production in aggregatibacter actinomycetemcomitans and Porphyromonas gingivalis. Photodiag. Photodyn. Ther. 17, 115-123 (2017). 